\title{
Acarnidae (Porifera: Demospongiae: Poecilosclerida) from the Mexican Pacific Ocean with the description of six new species
}

\author{
JOSE MARIA AGUILAR-CAMACHO, JOSE LUIS CARBALLO \\ and JOSE ANTONIO CRUZ-BARRAZA \\ Instituto de Ciencias del Mar y Limnología, Universidad Nacional Autónoma de México (Estación Mazatlán). Avenida Joel \\ Montes Camarena s/n, Mazatlán, México C.P.82000, PO Box 811. E-mail: jmaguilarcam@ gmail.com
}

\begin{abstract}
SUMMARY: The family Acarnidae is characterized by sponges with ectosomal diactinal spicules and choanosomal monactinal spicules. Microscleres include palmate isochelae, toxas and echinating acanthostyles. We described ten species from the Mexican Pacific Ocean. Six of them are new to science: Acarnus michoacanensis n. sp., Acarnus oaxaquensis n. sp., Acarnus sabulum n. sp., Acheliderma fulvum n. sp., Megaciella toxispinosa n. sp. and Iophon bipocillum n. sp. Four are known in Eastern Pacific waters: Acarnus erithacus, Acarnus peruanus, Megaciella microtoxa and Iophon indentatum.
\end{abstract}

Keywords: Porifera, Acarnidae, Mexican Pacific, taxonomy, new species.

RESUMEN: Acarnidae (Porifera: Demospongiae: Poecilosclerida) del PaCifico MeXicano con la descripción de SEIS NUEVAS ESPECIES. - La familia Acarnidae se caracteriza por esponjas con espículas diactinas ectosómicas y espículas monactinas coanosómicas. Microscleras incluyen isoquelas palmadas, toxas y acantostilos. Se describen diez especies de distintas localidades del Pacífico mexicano. Seis de ellas son nuevas para la ciencia: Acarnus michoacanensis n. sp., Acarnus oaxaquensis n. sp., Acarnus sabulum n. sp., Acheliderma fulvum n. sp., Megaciella toxispinosa $\mathrm{n}$. sp. y Iophon bipocillum n. sp. Cuatro son conocidas para aguas del Pacífico Este: Acarnus erithacus, Acarnus peruanus, Megaciella microtoxa y Iophon indentatum.

Palabras clave: Porifera, Acarnidae, Pacífico mexicano, taxonomía, nuevas especies.

\section{INTRODUCTION}

The systematics of the order Poecilosclerida is currently based on the chelae and the spicule shape (Hajdu et al. 1994). The family Acarnidae (Poecilosclerida: Microcionina) is characterized by sponges with a tangential ectosomal skeleton made of tylotes with smooth or microspined heads (Hooper 2002a). The choanosomal skeleton has different arrangements: plumoreticulate, halichondriid, hymedesmoid or isotropic (van Soest et al. 1994). Microscleres, if present, include palmate isochelae, toxas and echinating acanthostyles (Hooper 2002a). However, species of the genus Iophon bear anisochelae and bipocilla as microscleres (Desqueyroux-Faúndez and van Soest 1996). The principal difference between the families Acarnidae and Microcionidae is the ectosomal spicule morphology: diactinal in Acarnidae and monactinal in Microcionidae (Hooper 2002a). Species of Acarnidae have an encrusting growth form, living over and under the rocks, crevices and vertical walls (van Soest et al. 1994). Species of the genera Zyzzya and Paracornulum can burrow carbonate structures such as corals and bivalve shells (Hooper 2002a).

In this contribution, we described ten species of this family from the Mexican Pacific Coast. Acarnus erithacus de Laubenfels, 1927 is described based on material from the Pacific Coast of USA and from the 


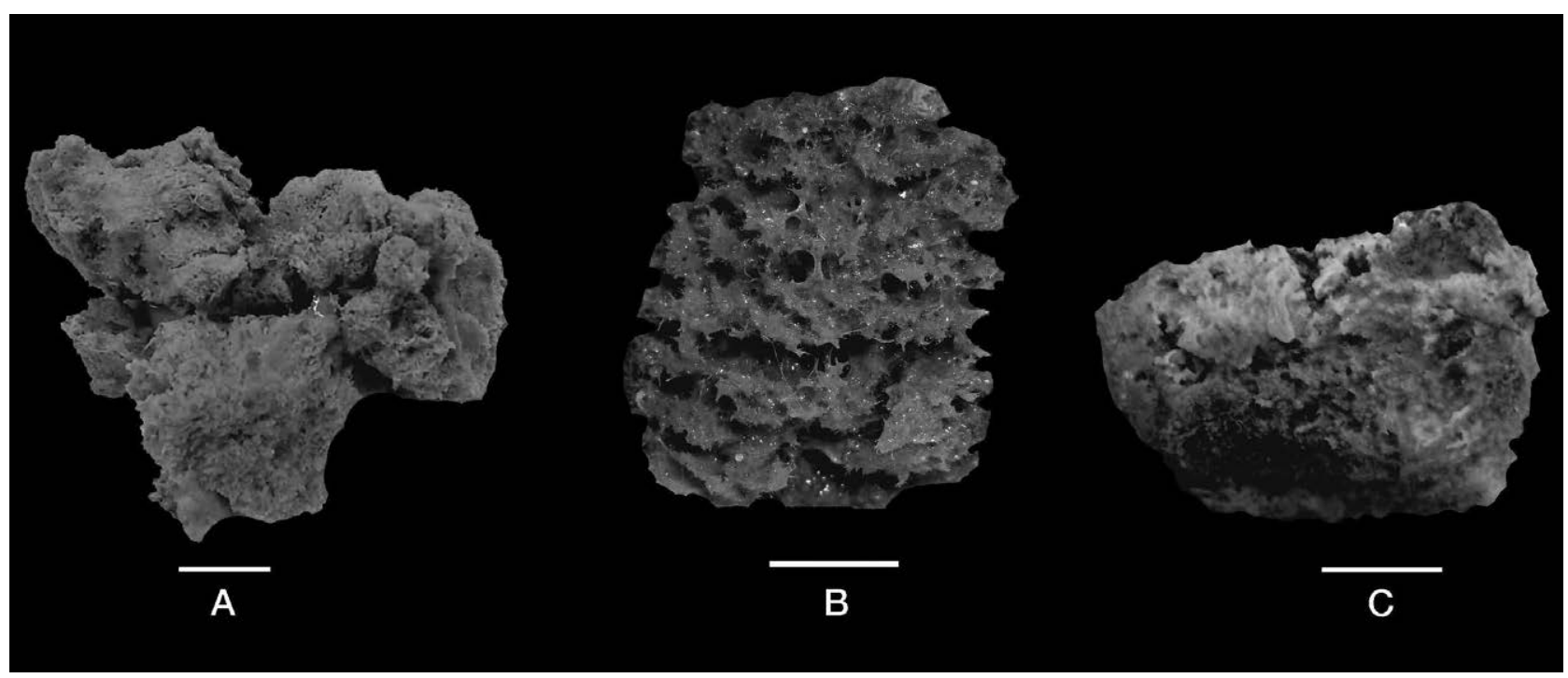

Fig. 1. - A, Acarnus erithacus de Laubenfels, 1927 Fragment of the Allan Hancock Pacific Expedition (AHF 1085-40). B, Vase-shaped sponge from deeper waters. C, Acarnus peruanus van Soest et al., 1991 Preserved specimen from the Mexican Pacific. Scale: A, B, $1.5 \mathrm{~cm}$ : $\mathrm{C}, 1 \mathrm{~cm}$

Gulf of California. Acarnus peruanus van Soest et al. 1991, originally described from Peru, is reported for first time from the northeast Pacific Coast. We redescribed and established a neotype for Megaciella microtoxa (Dickinson, 1945). Iophon indentatum Wilson, 1904 is described on material from the Gulf of California. We propose six species new to science: Acarnus michoacanensis n. sp., Acarnus oaxaquensis n. sp., Acarnus sabulum n. sp., Acheliderma fulvum n. sp., Megaciella toxispinosa n. sp. and Iophon bipocillum $\mathrm{n}$. sp. Based on the literature, we discuss the genus Acheliderma Topsent, 1892 and consider that the monotypic genus Fusifer Dendy, 1896 is not a junior synonym of Acheliderma. We discuss the genus Megaciella Hallman, 1920 and consider that some species do not have the morphological diagnostic features of this genus.

\section{MATERIAL AND METHODS}

Specimens from shallow waters were collected by snorkeling and scuba diving; specimens from deeper waters by bottom trawling. Sponges were fixed in formaldehyde $4 \%$ and transferred in ethanol $70 \%$ for preservation. Spicule and skeleton preparation for light and electron microscopy (SEM) followed the techniques described by Boury-Esnault and Rützler (1997). Twenty-five spicules of each category chosen at random were measured for each specimen. The minimum-(average)-maximum measurement for each spicule category was calculated.

Holotypes were deposited in the Museo de Ciencias Naturales de Madrid (MCNM), and paratypes in the "Colección de Esponjas del Pacífico Mexicano" (LEBICML-UNAM). Additional material from Los Angeles County Museum (LACM) and the Allan Hancock Foundation (AHF) was also examined.

\section{SYSTEMATICS}

Class DEMOSPONGIAE Sollas, 1885

Order POECILOSCLERIDA Topsent, 1928

Suborder MICROCIONINA Hajdu, van Soest and Hooper, 1994

Family ACARNIDAE Dendy, 1922

Genus Acarnus Gray, 1867

Remarks. Acarnus is a monophyletic taxon based on the presence of the cladotylote spicule which is considered a synapomorphic character of the genus in the family Acarnidae. The genus Acarnus is divided into three main groups according to some morphological features: The "innominatus" species group (A. innominatus), the "tortilis" species group (A. tortilis), and the "souriei" species group (A. souriei) (see van Soest et al. 1991).

\section{"Innominatus" species group}

Remarks. Species of Acarnus belonging to the "innominatus" group have styles with a smooth base; the first cladotylote category has a smooth shaft and lacks hooks on the distal extremity. The skeleton is renieroid or isotropic occasionally obscured by an anisotropic arrangement (see van Soest et al. 1991).

Acarnus erithacus de Laubenfels, 1927 (Figs 1A, B and 2, Table 1)

Acarnus erithacus de Laubenfels, 1927: 258-260, 1932: 104107. Dickinson, 1945:19. Bakus, 1966: 468-471. Hofknecht, 1978:54. van Soest et al. 1991: 58-59. Lee et al. 2007:135.

Holotype. U.S.N.M. 21430, 24/01/1924, Santa Catalina Island, (California). $33 \mathrm{~m}$ (not examined)

Material examined. Paratype: LACM \# 21416 Santa Catalina Island, 28/01/1924, 36 m Univ. South of California. L35545 D66, 


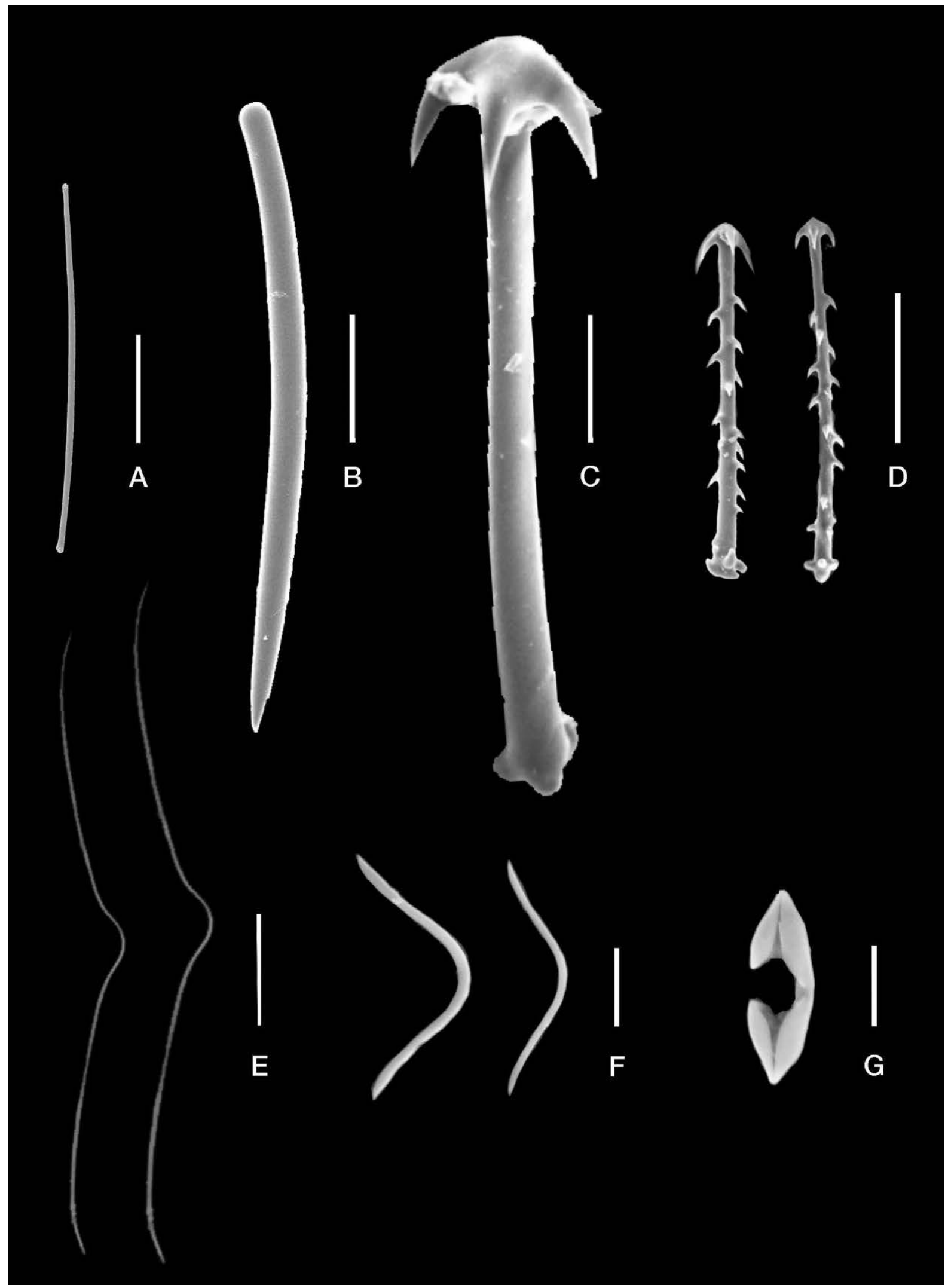

Fig. 2. - Acarnus erithacus de Laubenfels, 1927 (Allan Hancock specimen). A, Ectosomal tylote with microspined heads. B, Choanosomal style. C, Cladotylote I smooth with four clades. D, Cladotylotes II microspined with four clades. E, Toxas I. F, Toxas II. G, Palmate isochela. Scale: A, D, $60 \mu \mathrm{m}$; B, $50 \mu \mathrm{m}$; C, F, $40 \mu \mathrm{m} ; \mathrm{E}, 30 \mu \mathrm{m} ; \mathrm{G}, 3 \mu \mathrm{m}$. 
680 - J.M. Aguilar-Camacho et al.

TABLE 1. - Spicule measurements of Acarnus erithacus de Laubenfels, 1927. Values are expressed in minimum-average-maximum ( $\mu$ m).

\begin{tabular}{|c|c|c|c|c|c|c|}
\hline $\begin{array}{l}\text { Material } \\
\text { examined }\end{array}$ & $\begin{array}{c}\text { Tylotes } \\
\text { (length } \times \text { width) }\end{array}$ & $\begin{array}{c}\text { Styles } \\
\text { (length } \times \text { width) }\end{array}$ & $\begin{array}{l}\text { Cladotylotes } \\
\text { (length } \times \\
\text { width } \times \\
\text { cladome width) }\end{array}$ & $\begin{array}{l}\text { Toxas } \\
\text { (length) }\end{array}$ & $\begin{array}{l}\text { Palmate } \\
\text { isochelae } \\
\text { (length) }\end{array}$ & Locality and depth \\
\hline \#21416 & $\begin{array}{l}180-(226.4)-265 \times \\
2.5-(3.7)-5\end{array}$ & $\begin{array}{l}355-(375.2)-400 \times \\
7.5-(13.4)-17.5\end{array}$ & $\begin{array}{l}\text { I.- } 170-(192.9)-225 \times \\
\text { 5-(9.1)-15x } \\
\text { 12.5-(17.5)-30 } \\
\text { II.- } 70-(74.6)-85 \times \\
\text { 2.5-(2.9)-5x5-(6.8)-7.5 }\end{array}$ & $\begin{array}{l}\text { I.-295-(361.1)-450 } \\
\text { II.-145-(191.3)-250 } \\
\text { III.- 40-(72.3)-100 } \\
\text { IV.- 25-(46.9)-70 }\end{array}$ & $10-(13.4)-15$ & $\begin{array}{l}\text { Santa Catalina } \\
\text { Island, California. } \\
36 \mathrm{~m} \text {. }\end{array}$ \\
\hline AHF-1058-40 & $\begin{array}{l}185-(212.5)-250 \times \\
2.5-(3.2)-5\end{array}$ & $\begin{array}{l}315-(381.6)-440 \times \\
7.5-(17.6)-25\end{array}$ & $\begin{array}{l}\text { I.-190-(230.5)-250× } \\
7.5-(12.4)-17.5 \times \\
12.5-(22.8)-35 \\
\text { II.-65-(77.5)-90x } \\
2.5-(3.1)-5 \times 7.5-(8.7)-10\end{array}$ & $\begin{array}{l}\text { I.-230-(332.5)-410 } \\
\text { II.-100-(140.6)-185 } \\
\text { III.-55-(62.8)-90 } \\
\text { IV.-25-(49.1)-65 }\end{array}$ & $12.5-(13.9)-15$ & $\begin{array}{l}\text { San Pedro Nolasco, } \\
\text { Gulf of California. } \\
70 \mathrm{~m} \text {. }\end{array}$ \\
\hline LEB-342 & $\begin{array}{l}160-(188.6)-225 \times \\
2.5-(3.8)-7.5\end{array}$ & $\begin{array}{l}230-(335.5)-390 \times \\
7.5-(14.5)-20\end{array}$ & $\begin{array}{l}\text { I.-140-(176.1)-245x } \\
5-(10.5)-15 \times \\
15-(20.1)-30 \\
\text { II.-70-(84.9)-105x } \\
2.5-(3.1)-5 \times 5-(6.3)-7.5\end{array}$ & $\begin{array}{l}\text { I.-255-(301.1)-360 } \\
\text { II.-110-(143.5)-200 } \\
\text { III.-35-(50.2)-100 } \\
\text { IV.-25-(38.6)-55 }\end{array}$ & $10-(12.7)-15$ & $\begin{array}{l}\text { Isla Tiburón, } \\
\text { Sonora. } 15 \mathrm{~m} .\end{array}$ \\
\hline LEB-2052 & $\begin{array}{l}260-(320.1)-360 \times \\
2.5-(4.2)-5\end{array}$ & $\begin{array}{l}580-(673.2)-760 \times \\
25-(33.6)-40\end{array}$ & $\begin{array}{l}\text { I.- } 360-(414.4)-480 \times \\
17.5-(21.3)-25 \times \\
35-(53.3)-60 \\
\text { II.- } 115-(128.7)-135 \times \\
2.5-(4.1)-5 \times 10-(14.1)-15\end{array}$ & $\begin{array}{l}\text { I.-350-(428.5)-530 } \\
\text { II.-140-(167.5)-200 } \\
\text { III.- 60-(82.2)-100 } \\
\text { IV.- 50-(61.4)-70 }\end{array}$ & $15-(16.2)-17.5$ & $\begin{array}{l}\text { Gulf of California. } \\
122 \mathrm{~m} \text {. }\end{array}$ \\
\hline LEB-2053 & $\begin{array}{l}310-(358.5)-410 \times \\
2.5-(4.3)-5\end{array}$ & $\begin{array}{l}\text { 605-(712.1)-810x } \\
30-(37.2)-45\end{array}$ & $\begin{array}{l}\text { I.- } 400-(426.4)-460 \times \\
15-(17.5)-25 \times \\
50-(59.6)-70 \\
\text { II.- } 115-(145.2)-180 \times \\
2.5-(4.3)-5 \times \\
12.5-(14.1)-15\end{array}$ & $\begin{array}{l}\text { I.-330-(368.2)-410 } \\
\text { II.-140-(168.3)-200 } \\
\text { III.- 70-(80.3)-110 } \\
\text { IV.- 50-(71.6)-100 }\end{array}$ & $15-(16.2)-17.5$ & $\begin{array}{l}\text { Gulf of California. } \\
122 \mathrm{~m}\end{array}$ \\
\hline LEB-2054 & $\begin{array}{l}225-(301.5)-355 \times \\
2.5-(4.5)-5\end{array}$ & $\begin{array}{l}730-(775.4)-840 \times \\
35-(43.3)-50\end{array}$ & $\begin{array}{l}\text { I.- } 410-(444.5)-480 \times \\
15-(19.5)-25 \times \\
50-(63.8)-80 \\
\text { II.- } 120-(139.5)-180 \times \\
2.5-(3.9)-5 \times \\
10-(16.7)-20\end{array}$ & $\begin{array}{l}\text { I.-280-(428.8)-530 } \\
\text { II.- } 105-(169.4)-230 \\
\text { III.- 50-(85.7)-140 } \\
\text { IV.- 45-(55.8)-75 }\end{array}$ & $15-(16.3)-17.5$ & $\begin{array}{l}\text { Gulf of California. } \\
122 \mathrm{~m} \text {. }\end{array}$ \\
\hline LEB-2055 & $\begin{array}{l}250-(320.1)-420 \times \\
2.5-(4.1)-5\end{array}$ & $\begin{array}{l}690-(771.5)-850 \times \\
30-(37.5)-45\end{array}$ & $\begin{array}{l}\text { I.- } 390-(518.8)-610 \times \\
17.5-(21.9)-25 \times \\
60-(77.7)-90 \\
\text { II.- } 140-(167.8)-180 \times \\
2.5-(3.2)-5 \times \\
15-(16.7)-20\end{array}$ & $\begin{array}{l}\text { I.-370-(465.1)-650 } \\
\text { II.-115-(178.2)-230 } \\
\text { III.- 65-(75.5)-90 } \\
\text { IV.- 35-(59.1)-80 }\end{array}$ & $15-(16.4)-17.5$ & $\begin{array}{l}\text { Gulf of California. } \\
122 \mathrm{~m} \text {. }\end{array}$ \\
\hline
\end{tabular}

06/02/1940, San Pedro Nolasco Gulf of California (MEX), $70 \mathrm{~m}$. R/V VELERO III. AHF 1085-40 (Dickinson, 1945). 342-LEBICML-UNAM, 27/04/2001, Isla Tiburón (Hermosillo, Sonora)

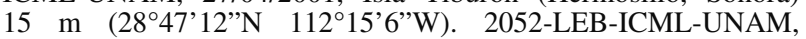
11/04/2011, 32 Station Talud XIV (Gulf of California, MEX) $122 \mathrm{~m}$ (27 $56^{\prime} 13^{\prime \prime N} 111^{\circ} 19^{\prime} 44^{\prime}$ 'W). 2053-LEB-ICML-UNAM, 11/04/2011, 32 Station Talud XIV (Gulf of California, MEX) $122 \mathrm{~m}\left(27^{\circ} 56^{\prime} 13^{\prime \prime} \mathrm{N} 111^{\circ} 19^{\prime} 44^{\prime \prime} \mathrm{W}\right)$. 2054-LEB-ICML-UNAM, 11/04/2011, 32 Station Talud XIV (Gulf of California, MEX) $122 \mathrm{~m}\left(27^{\circ} 56^{\prime} 13^{\prime} \mathrm{N} 111^{\circ} 19^{\prime} 44^{\prime} \mathrm{W}\right)$. 2055-LEB-ICML-UNAM, 11/04/2011, 32 Station Talud XIV (Gulf of California, MEX) $122 \mathrm{~m}$

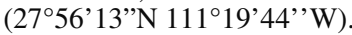

Description. Massive, cushion-shaped or vaseshaped sponge $4-10 \mathrm{~cm}$ long and 1-7 cm thick. Surface uneven. Oscula circular to oval shaped $(1-2 \mathrm{~cm}$ long $\times 5-8 \mathrm{~mm}$ high), ostia elliptical (600-800 $\mu \mathrm{m}$ long) and unevenly distributed. Texture hard and difficult to tear. Colour in life red or brown, pale in preservation (Fig. 1A, B).

Skeleton. Ectosomal tylotes straight with microspined heads: $160-420 \times 2.5-7.5 \mu \mathrm{m}$ (Fig. 2A). Choanosomal styles straight or curved: $230-850 \times 7.5-50$ $\mu \mathrm{m}$ (Fig. 2B). Cladotylotes with three to four clades in two categories: I, long, thick and smooth (180-610 $\times 5$ $25 \mu \mathrm{m}$ ), cladome 12.5-90 $\mu \mathrm{m}$ (Fig. 2C); II, short and microspined $(65-180 \times 2.5-5 \mu \mathrm{m})$, cladome 5-20 $\mu \mathrm{m}$ (Fig. 2D). Toxas with a pronounced curvature in two categories: I, long and thick $(230-650 \mu \mathrm{m})$. II, short and thin (100-250 $\mu \mathrm{m})$ (Fig. 2E). Oxhorn toxas in two categories: I, thick $(35-140 \mu \mathrm{m})$; II, thin $(25-100 \mu \mathrm{m})$ (Fig. 2F). Palmate isochelae with the alae fused to the shaft $(10-15 \mu \mathrm{m})$ (Fig. 2G). The ectosomal skeleton is a dense layer of tylotes (30-60 $\mu \mathrm{m}$ thick). The choanosomal skeleton is an isotropic reticulum of ascending multispicular fibres (80-250 $\mu \mathrm{m}$ thick), interconnected by secondary multispicular fibres (30-150 um thick). The organization forms rectangular and quadrangular meshes (160-300 $\mu \mathrm{m}$ wide). Microscleres are dispersed with no special organization.

Remarks: Acarnus erithacus de Laubenfels, 1927 is a subtidal and deep-sea species found on the Pacific Coast of USA (Bakus 1966) and in the Gulf of California (Dickinson 1945, Hofknecht 1978). We found differences in the length and the width of the styles and 


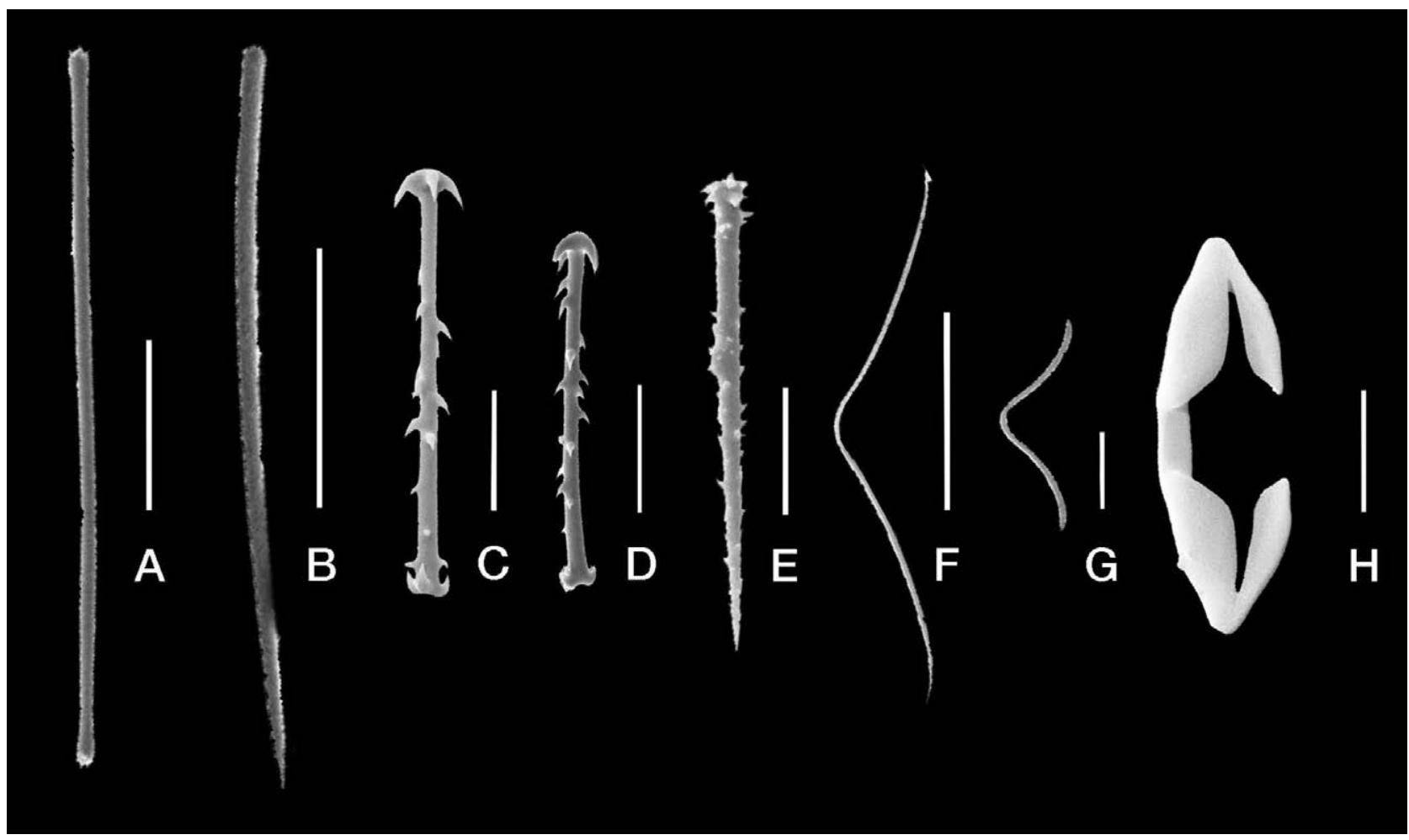

FIG. 3. - Acarnus peruanus van Soest et al., 1991. A, Ectosomal tylote with microspined heads. B, Choanosomal style. C, Cladoylote I microspined with four clades. D, Cladotylote II microspined with four clades. E, Echinating acanthostyle. F, Toxa I. G, Toxa II. H, Palmate isochela. Scale: A, D, $35 \mu \mathrm{m}$; B, F, $80 \mu \mathrm{m}$; C, E, G, $30 \mu \mathrm{m}$; D, $35 \mu \mathrm{m}, \mathrm{H}, 3.5 \mu \mathrm{m}$.

TABle 2. - Comparative table data of the Acarnus species of the "souriei" group from the Mexican Pacific and other specific worldwide localities. Values are expressed in minimum-average-maximum $(\mu \mathrm{m})$. *Spicule measurements from the original description.

\begin{tabular}{|c|c|c|c|c|c|c|c|}
\hline $\begin{array}{l}\text { Material } \\
\text { examined }\end{array}$ & $\begin{array}{c}\text { Tylotes } \\
\text { (length×width) }\end{array}$ & $\begin{array}{c}\text { Styles } \\
\text { (length } \times \text { width) }\end{array}$ & $\begin{array}{l}\text { Acanthostyles } \\
\text { (length×width) }\end{array}$ & $\begin{array}{l}\text { Cladotylotes } \\
\text { (length } \times \text { width } \times \\
\text { cladome width) }\end{array}$ & $\begin{array}{l}\text { Toxas } \\
\text { (length) }\end{array}$ & $\begin{array}{l}\text { Palmate } \\
\text { isochelae } \\
\text { (length) }\end{array}$ & $\begin{array}{c}\text { Locality and } \\
\text { depth }\end{array}$ \\
\hline $\begin{array}{l}\text { A. peruanus } \\
\text { LEB- } 727\end{array}$ & $\begin{array}{l}117.5-(176.5)- \\
200 \times 2.5-(4.2)-5\end{array}$ & $\begin{array}{l}150-(267.3)- \\
355 \times 7.5-(10.6)- \\
12.5\end{array}$ & $\begin{array}{l}75-(84.8)-98 \times \\
2.5-(4.8)-6.3\end{array}$ & $\begin{array}{l}\text { I.- } 97.5-(118)-138 \times \\
6.3-(7)-10 \times \\
9-(17.6)-22.5 \\
\text { II.- } 57.5-(67.8)-75 \times \\
2.5-(3.3)-4 \times \\
7.5-(6.8)-15\end{array}$ & $\begin{array}{l}\text { I.-125- } \\
\text { (166.6)-210 } \\
\text { II.-25-(41)- } \\
75\end{array}$ & $\begin{array}{l}12-(13.8)- \\
17.5\end{array}$ & $\begin{array}{l}\text { Puente } \\
\text { Maviri, } \\
\text { Sinaloa. } \\
5 \mathrm{~m} .\end{array}$ \\
\hline $\begin{array}{l}\text { A. peruanus van } \\
\text { Soest } \text { et al. } 1991^{*}\end{array}$ & $137-184 \times 73-4$ & $244-371 \times 9-12$ & $82-97 \times 4$ & $\begin{array}{l}\text { I.- } 121-141 \times 4-5 \\
\text { II.- } 6-75 \times 3\end{array}$ & $\begin{array}{l}\text { I.- } 188-211 \\
\text { II.-35-40 }\end{array}$ & $13-17$ & $\begin{array}{l}\text { Isla Lobos, } \\
\text { Peru. Depth } \\
\text { unknown. }\end{array}$ \\
\hline \multicolumn{8}{|l|}{$\begin{array}{l}\text { A. michoacanensis } \\
\text { n. sp. }\end{array}$} \\
\hline MNCM 1.01/688 & $\begin{array}{l}175-(220.5)-260 \\
\times 2.5-(3.6)-5\end{array}$ & $\begin{array}{l}207.5-(265.7)- \\
277 \times 5-(6.7)- \\
8 \times 5.5-(7.2)-8.8\end{array}$ & $\begin{array}{l}62.5-(68.1)-72.5 \times \\
4-(4.7)-5.5\end{array}$ & $\begin{array}{l}115-(123.2)-135 \times \\
2.5-(2.7)-3 \times \\
12.5-(12.9)-14\end{array}$ & $\begin{array}{l}\text { I.- } 165- \\
\text { (173.1)-205 } \\
\text { II.- } 47.5- \\
(65.5)-90\end{array}$ & $\begin{array}{l}11.5-(12)- \\
12.5\end{array}$ & $\begin{array}{l}\text { Michoacan. } \\
8 \mathrm{~m} .\end{array}$ \\
\hline LEB-1281 & $\begin{array}{l}155-(210)-260 \\
\times 2.5-(3.6)-5\end{array}$ & $\begin{array}{l}207.5-(285)- \\
277 \times 5-(6.7)- \\
8 \times 5.5-(7.2)-8.8\end{array}$ & $\begin{array}{l}47.5-(64.2)-72.5 \times \\
4-(4.7)-5.5\end{array}$ & $\begin{array}{l}112.5-(121)-135 \times \\
2.5-(2.8)-3 \times \\
10.5-(12.1)-14\end{array}$ & $\begin{array}{l}\text { I.- } 152- \\
\text { (188.5)-210 } \\
\text { II.- 42-(55)- } \\
92.5\end{array}$ & $\begin{array}{l}11.25- \\
(12.25)- \\
12.5\end{array}$ & $\begin{array}{l}\text { Michoacan. } \\
8 \mathrm{~m} \text {. }\end{array}$ \\
\hline $\begin{array}{l}\text { A. souriei } \\
\text { (Lévi, 1952)* }\end{array}$ & $210-270 \times 3$ & $180-230 \times 3-10$ & $\begin{array}{l}\text { I.- } 100-165 \\
\text { II. } 76-80\end{array}$ & $105-160 \times 5$ & $\begin{array}{l}\text { I.-80 } \\
\text { II.-150 } \\
\text { III.-190 }\end{array}$ & 14 & $\begin{array}{l}\text { Senegal. } \\
1-30 \mathrm{~m} .\end{array}$ \\
\hline $\begin{array}{l}\text { A. radovani } \\
\text { (Boury-Esnault, } \\
\text { 1973)* }\end{array}$ & $350-380 \times 3-5$ & $50 \times 3-9$ & $\begin{array}{l}\text { I-. } 95-141 \\
\text { II.- }-75-82\end{array}$ & $170-220 \times 4-6$ & $\begin{array}{l}\text { I.-70-105 } \\
\text { II.-50-205 } \\
\text { III.-? }\end{array}$ & $10-22$ & $\begin{array}{l}\text { NE Brazil } \\
\text { Island. } 51 \mathrm{~m} .\end{array}$ \\
\hline $\begin{array}{l}\text { A. tener } \\
\quad \text { Tanita, 1963* }\end{array}$ & $180-320 \times 2.5-5$ & $260-340 \times 8-10$ & $80-130 \times 5-6$ & $130-190$ & $70-110$ & $12-14$ & $\begin{array}{l}\text { Gambier, } \\
\text { Japan. Depth } \\
\text { unknown. }\end{array}$ \\
\hline
\end{tabular}


cladotylotes I of specimens collected from deeper waters (Table 1). However, we assumed that it is the same species, because the material examined was found in the same geographical area and bears the same spicule elements. The differences in the spicule measurements of A. erithacus may be attributable to dissolve silica in the water, as has been demonstrated in other sponge species (see Uriz et al. 2000).

\section{"Souriei" species group}

Remarks. Species of Acarnus belonging to the "souriei" group are characterized mainly by the possession of acanthostyles which are considered a synapomorphic feature, because they are present in many genera and families of the order Poecilosclerida (van Soest et al. 1991).

Acarnus peruanus van Soest, Hooper and Hiemstra, 1991 (Figs 1C and 3, Table 2)

Acarnus peruanus van Soest et al. 1991: 70.

Holotype. U.S.N.M. 23264 Isla Lobos (Peru) $07^{\circ} \mathrm{S} 80^{\circ} \mathrm{W}$ depth unknown (Not examined)
Material examined. 727-LEB-ICML-UNAM, 14/11/2002: Puente Maviri (Sinaloa), $5 \mathrm{~m},\left(25^{\circ} 34^{\prime} 55^{\prime}\right.$ N $109^{\circ} 06$ ' $52^{\prime}$ 'W).

Description. Encrusting sponge growing over rocks from $5 \mathrm{~cm}$ long and 1-3 mm thick. Surface smooth. Oscula circular (1.5 mm in diameter) and ostia circular to oval-shaped (0.8-1.2 $\mathrm{mm}$ in diameter) and evenly distributed. Consistency compressible and easy to tear. Colour in life red or light brown, pale in preservation (Fig. 1C).

Skeleton. Ectosomal tylotes straight with microspined heads: $117.5-200 \times 2.5-5 \mu \mathrm{m}$ (Fig. 3A). Choanosomal styles straight or slightly curved, with smooth or microspined base: 150-355×7.5-12.5 $\mu \mathrm{m}$ (Fig. 3B). Cladotylotes microspined with four clades in two categories: I, 97-138×6.3-10 $\mu \mathrm{m}$, cladome 9-22.5 $\mu \mathrm{m}$ (Fig.

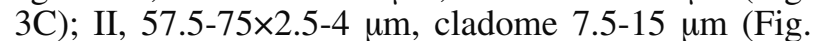
3D). Acanthostyles with short spines: $75-98 \times 2.5-6.3$ $\mu \mathrm{m}$ (Fig. 3E). Toxas in two categories: I, elongated with a slightly curvature in the middle $(125-210 \mu \mathrm{m})$ (Fig. 3F); II, thin and slightly curved (25-75 $\mu \mathrm{m})$ (Fig. 3G). Palmate isochelae with the alae fused to the shaft: 12-17.5 $\mu \mathrm{m}$ (Fig. 3H). The ectosome is a tangential layer of tylotes (80-170 $\mu \mathrm{m}$ thick). The choanosomal

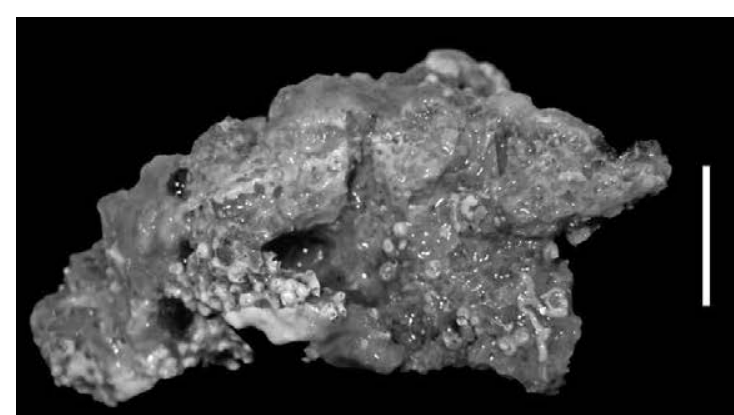

A

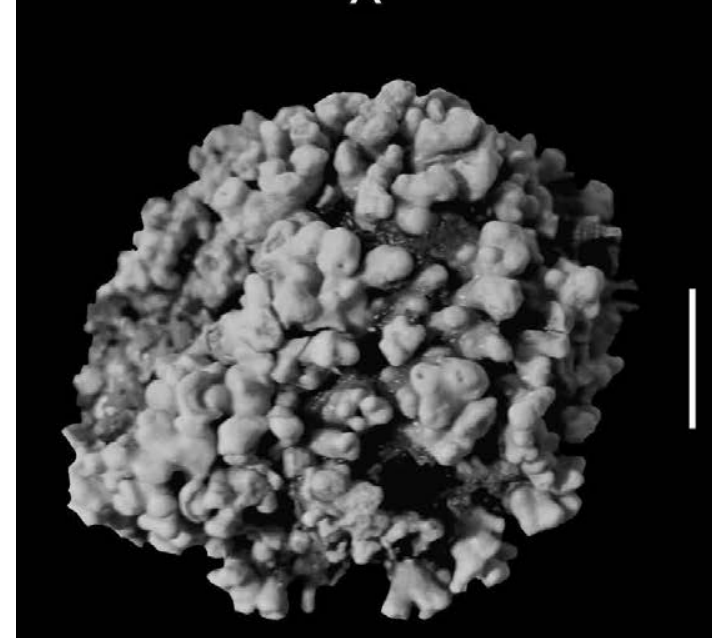

C

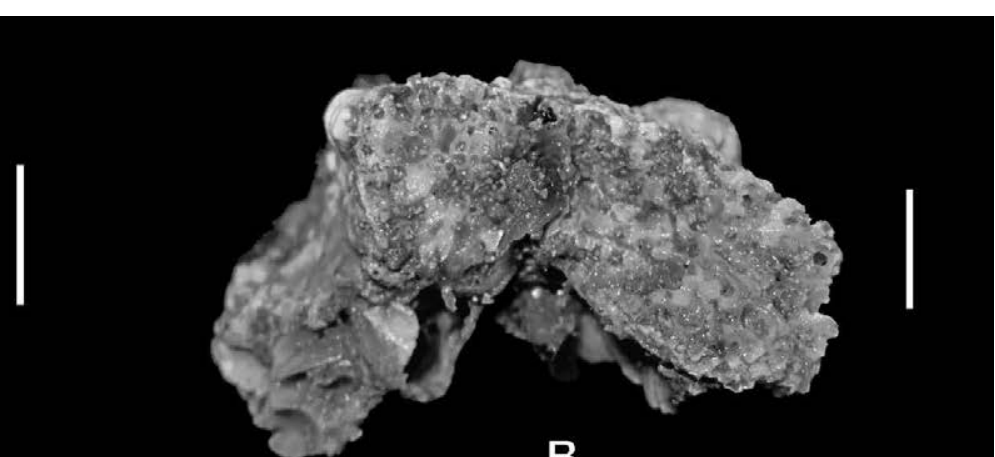

B

FIG. 4. - A, Acarnus michoacanensis n. sp. Preserved specimen growing over coral frame. B, Acarnus oaxaquensis n. sp. Preserved encrusting sponge growing over coral frame. C, Acarnus sabulum n. sp. Preserved specimen growing over rhodolits. D, Acheliderma fulvum n. sp. Preserved encrusting sponge. Scale: A, B, C, $1 \mathrm{~cm} ; \mathrm{D}, 2 \mathrm{~cm}$. 


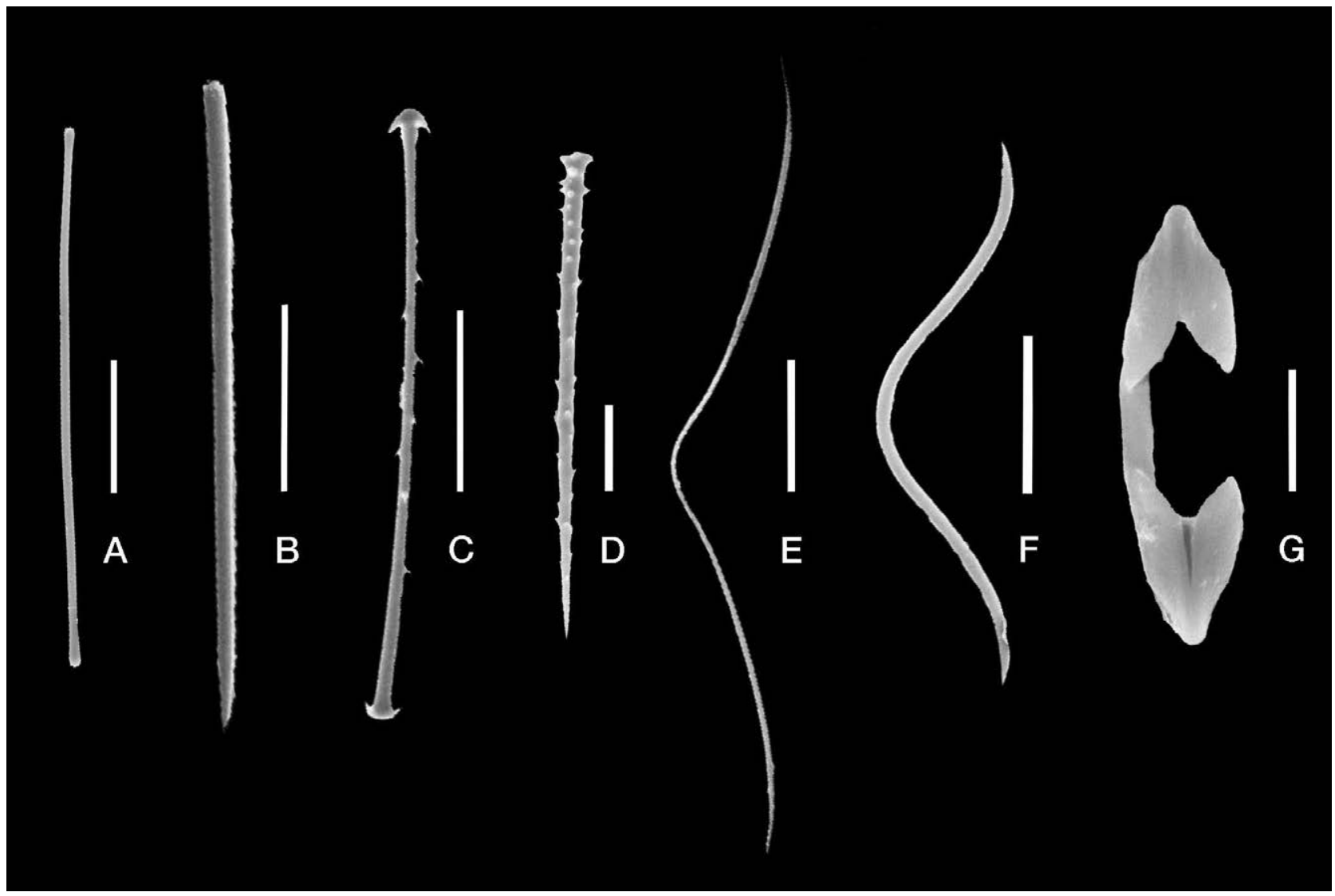

FIG. 5. - Acarnus michoacanensis n. sp. A, Ectosomal tylote with microspined heads. B, Choanosomal style with microspined base. C, Cladoylote microspined with four clades. D, Echinating acanthostyle. E, Toxa I. F, Toxa II. G, Palmate isochela. Scale: A, E, 35 um; B, 60 $\mu \mathrm{m} ; \mathrm{C}, 30 \mu \mathrm{m} ; \mathrm{D}, 10 \mu \mathrm{m} ; \mathrm{F}, 25 \mu \mathrm{m} ; \mathrm{G}, 3 \mu \mathrm{m}$.

skeleton is an isotropic reticulum of multispicular ascending primary fibres (40-90 $\mu \mathrm{m}$ thick). Interconnected by secondary pauci- or multispicular fibres (25-30 $\mu \mathrm{m}$ thick). Acanthostyles and cladotylotes are echinating the primary fibres. Microscleres are dispersed with no special organization.

Remarks: Acarnus peruanus van Soest et al. 1991 was originally described from the coast of Peru. The spicule measurements of the material examined match with the original description (Table 2). This is the first record of this species in the northeast Pacific Coast.

Acarnus michoacanensis n. sp. (Figs 4A and 5, Table 2)

Material examined. Holotype, MCNM 1.01/688, 05/24/2005, Faro de Bucerías (Michoacán) 8 m (18²0'56'N 103³0'33' 'W). Paratype: 1281-LEB-ICML-UNAM, 05/24/2005, Faro de Bucerías (Michoacán) $8 \mathrm{~m}\left(18^{\circ} 20^{\prime} 56^{\prime \prime} \mathrm{N} 103^{\circ} 30^{\prime} 33^{\prime \prime} \mathrm{W}\right)$.

Description. Thinly encrusting sponge ( $2 \mathrm{~mm}$ thick) growing into dead coral fragments. Surface hispid with spicules protruding externally. Consistency firm and somewhat crumbly. Colour in life not observed, pale to ochre in preservation (Fig. 4A).
Skeleton. Ectosomal tylotes with microspined heads: 155-260×2.5-5 $\mu \mathrm{m}$ (Fig. 5A). Choanosomal styles, slightly curved with microspined base: 207.5277 $\times 5-8 \mu \mathrm{m}$ (Fig. 5B). Cladotylotes microspined with four clades: $112.5-135 \times 2.5-3 \mu \mathrm{m}$; cladome $10.5-14 \mu \mathrm{m}$ (Fig. 5C). Acanthostyles covered with short spines: 47.5-72.5 $\times 4-5.5 \mu \mathrm{m}$ (Fig. 5D). Toxas in two categories: I, thin with a curvature in the middle (152-210 $\mu \mathrm{m})$ (Fig. 5E); II, wing-shaped (42-92.5 $\mu \mathrm{m})$ (Fig. 5F). Palmate isochelae with the alae fused to the shaft: 11.3$12.5 \mu \mathrm{m}$ (Fig. 5G). The ectosomal skeleton is a tangential layer of tylotes. The choanosomal skeleton is hymedesmoid. Main styles and acanthostyles are embedded in a spongin layer. Microscleres are dispersed with no special organization.

Etymology. Named "michoacanensis" because of the incidence of this species in Michoacan.

Remarks. Acarnus michoacanensis $\mathrm{n}$. $\mathrm{sp}$. is a subtidal species found in the South Eastern Pacific of Mexico (Michoacan). This species is morphologically similar to Acarnus peruanus van Soest et al. 1991. However, A. peruanus has cladotylotes in two categories and an isotropic skeleton, while A. michoacanensis $\mathrm{n}$. $\mathrm{sp}$. has one category of cladotylotes and an hymedesmoid skeleton. 


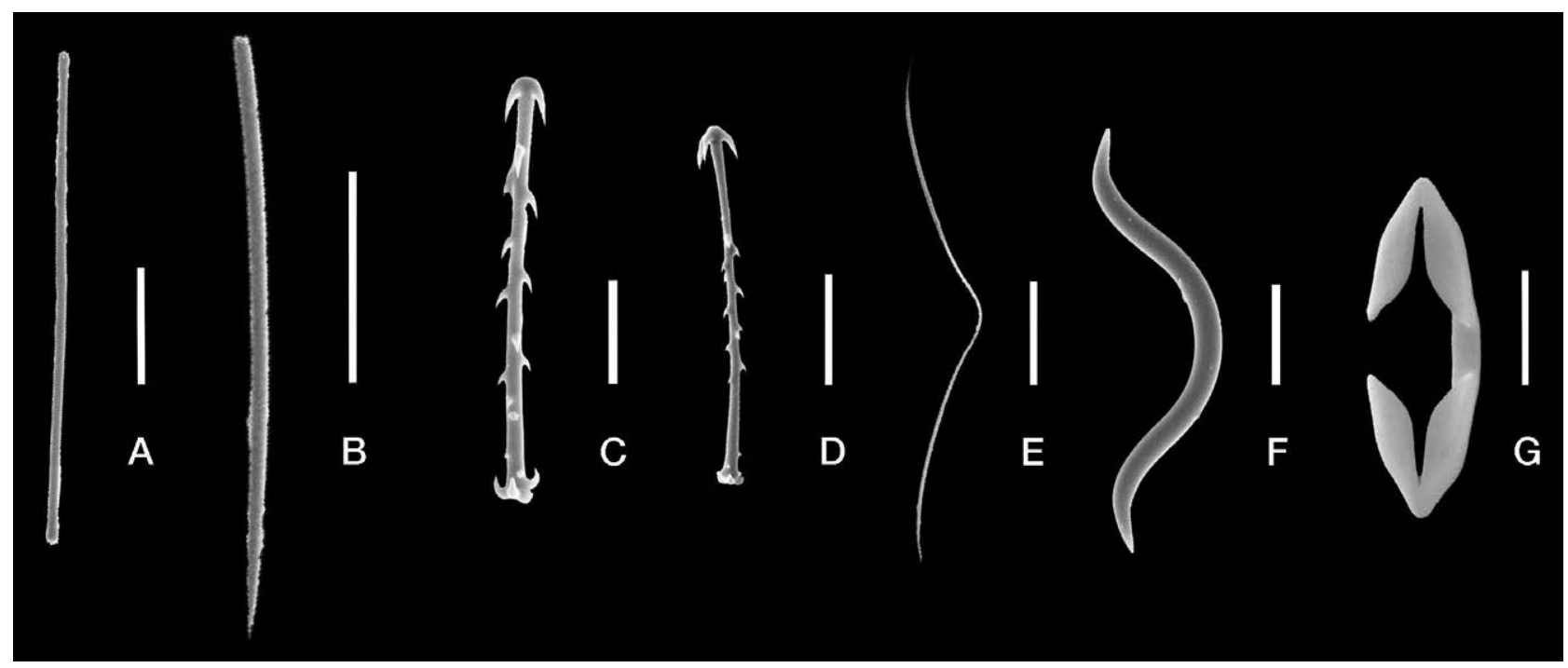

FIG. 6. - Acarnus oaxaquensis n. sp. A, Ectosomal tylote with microspined heads. B, Choanosomal style with microspined base. C, Cladoylote I microspined with four clades. D, Cladotylote II microspined with four clades. E, Toxa I. F, Toxa II. G, Palmate isochela. Scale: A, C, E, 35 $\mu \mathrm{m}$; B, $70 \mu \mathrm{m}$; D, $20 \mu \mathrm{m} ; \mathrm{F}, 25 \mu \mathrm{m} ; \mathrm{G}, 5 \mu \mathrm{m}$.

From the "souriei" species group, three species have cladotylotes in one category. A. souriei (Lévi, 1952) and A. radovani (Boury-Esnault, 1973) have two categories of acanthostyles and toxas in three sizes. A. michoacanensis n. sp. has one category of acanthostyles and toxas in two sizes. Acarnus tener Tanita, 1963 is an encrusting to massive sponge with a plumose skeleton formed by ascending tracts, while Acarnus michoacanensis n. sp. is an encrusting sponge with a hymedesmoid skeleton. The remaining species of the "souriei" group have some spiculae elements of different length than A. michoacanensis n. sp. (Table 2).

\section{"Tortilis" species group}

Remarks. Species of Acarnus belonging to the "tortilis" group are characterized by the lack of acanthostyles and the presence of two categories of cladotylotes microspined (van Soest et al. 1991).

\section{Acarnus oaxaquensis n. sp.}

(Figs 4B and 6, Table 3)

Material examined. Holotype, MCNM 1.01/689, 07/11/2005, Isla Cacaluta (Oaxaca) $4 \mathrm{~m}$ (15³8'23'N 96²9'01'W). Paratypes: 1178-LEB-ICML-UNAM, 07/11/2005, Isla Cacaluta (Oaxaca) $4 \mathrm{~m}$ (15³8'23”N 96²9'01'W). 1195-LEB-ICML-UNAM, 05/11/2005, Isla Cacaluta (Oaxaca) 4 m (15³8’23”N 96²9’01'W).

Description. Thinly encrusting sponge $(<1 \mathrm{~mm}$ thick), living inside and over coral cavities. Surface hispid, due to spicules protruding externally to the surface. Consistency fleshy and easy to tear. Colour in life not observed, pale brown or whitish in preservation (Fig. 4B).

Skeleton. Ectosomal tylotes straight with micro-

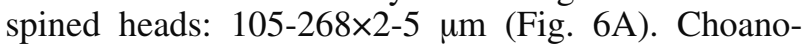

somal styles slightly curved with microspined base: 192.5-325×3-10 $\mu \mathrm{m}$ (Fig. 6B). Cladotylotes with three and four clades in two categories: I, long, thick and microspined (125-162.5×3-5 $\mu \mathrm{m})$, cladome 10-20 $\mu \mathrm{m}$ (Fig. 6C); II, short with microspined shaft (62.5$82.5 \times 2-3 \mu \mathrm{m}$ ), cladome 7.5-10 um (Fig. 6D). Toxas in two categories: I, thin and curved in variable sizes (35$170 \mu \mathrm{m})$ (Fig. 6E); II, oxhorn and thick (57.5-90 $\mu \mathrm{m})$ (Fig. 6F). Palmate isochelae with the alae fused to the shaft: 17.5-25 $\mu \mathrm{m}$ (Fig. 6G). The ectosomal skeleton is a dense layer of tylotes. The choanosomal skeleton is hymedesmoid. Main styles and cladotylotes are erected in a spongin layer. Microscleres are dispersed with no special organization.

Etymology. Named "oaxaquensis" because of the type locality.

Remarks. Acarnus oaxaquensis n. sp. is found on the southeast Pacific Coast of Mexico (Oaxaca). Currently, there are five species described worldwide belonging to the "tortilis group". The main difference of A. oaxaquensis $\mathrm{n}$. sp. from these species is that the tylotes are the shortest (Table 3).

\section{Acarnus sabulum n. sp.} (Figs 4C and 7, Table 3)

Material examined. Holotype, MCNM 1.01/690, 12/10/2008, CFE Bahía Magdalena (Baja California Sur) $3 \mathrm{~m}\left(24^{\circ} 48^{\prime} 45^{\prime} \mathrm{N}\right.$ 112 ${ }^{\circ} 05^{\prime} 59$ 'W). Paratypes: 1126-LEB-ICML-UNAM, 03/04/2005, Punta Pinta (Sonora), 4 m (31 20'14”N 11338'13'W). 2017-LEBICML-UNAM, 12/10/2008, CFE Bahía Magdalena (Baja California Sur) $3 \mathrm{~m}\left(24^{\circ} 48^{\prime} 45^{\prime \prime} \mathrm{N} 112^{\circ} 05^{\prime} 59^{\prime \prime} \mathrm{W}\right)$. 2018-LEB-ICML-UNAM, 12/10/2008, CFE Bahía Magdalena (Baja California Sur) $3 \mathrm{~m}$ (2448'45' N $\left.112^{\circ} 05^{\prime} 59^{\prime \prime} \mathrm{W}\right)$.

Description. Thinly encrusting sponge growing on rocky areas and rhodoliths, from 3 to $5 \mathrm{~mm}$ long 
TABLE 3. - Comparative table data of the Acarnus species of the "tortilis" group from the Mexican Pacific and other specific worldwide localities. Values are expressed in minimum-average-maximum $(\mu \mathrm{m}) . *$ Spicule measurements from the original description.

\begin{tabular}{|c|c|c|c|c|c|c|}
\hline $\begin{array}{l}\text { Material } \\
\text { examined }\end{array}$ & $\begin{array}{c}\text { Tylotes } \\
\text { (length } \times \text { width) }\end{array}$ & $\begin{array}{c}\text { Styles } \\
\text { (length×width) }\end{array}$ & $\begin{array}{l}\text { Cladotylotes } \\
\text { (length } \times \text { width } \times \\
\text { cladome width) }\end{array}$ & $\begin{array}{l}\text { Toxas } \\
\text { (length) }\end{array}$ & $\begin{array}{l}\text { Palmate } \\
\text { isochelae } \\
\text { (length) }\end{array}$ & $\begin{array}{l}\text { Locality and } \\
\text { depth }\end{array}$ \\
\hline \multicolumn{7}{|c|}{ Acarnus oaxaquensis n. sp. } \\
\hline MCNM 1.01/689 & $\begin{array}{l}165-(225.5)-265 \\
\times 2-(2.6)-3\end{array}$ & $\begin{array}{l}210-(242.5)-315 \\
\times 3-(5.5)-7.5\end{array}$ & 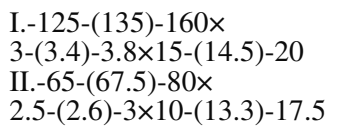 & $\begin{array}{l}\text { I.- } 45-(102.5)-155 \\
\text { II.-65-(72.5)-85 }\end{array}$ & 17.-(22.5)-25 & $\begin{array}{l}\text { Isla Cacaluta } \\
\text { (Oaxaca). } 4 \mathrm{~m} .\end{array}$ \\
\hline LEB-178 & $\begin{array}{l}165-(175)-257.5 \\
\times 2-(2.8)-3\end{array}$ & $\begin{array}{l}200-(256)-325 \\
\times 3-(4.9)-6.3\end{array}$ & 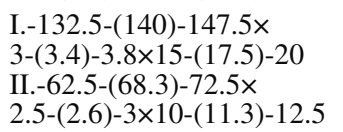 & $\begin{array}{l}\text { I.-35-(99)-170 } \\
\text { II.-57.5-(66)-75 }\end{array}$ & $17.5-(20)-22.5$ & $\begin{array}{l}\text { Isla Cacaluta } \\
\text { (Oaxaca). } 4 \mathrm{~m} .\end{array}$ \\
\hline LEB-1195 & $\begin{array}{l}105-(210)-268 \\
\times 2.5-(3.6)-5\end{array}$ & $\begin{array}{l}192.5-(236)-300 \\
\times 5-(6.5)-10\end{array}$ & $\begin{array}{l}\text { I.- } 125-(145)-162.5 \times \\
3.7-(4.3)-5 \times 10-(16.5)-20 \\
\text { II.-67.5-(75.5)-82.5× } \\
2-(2.4)-3 \times 7.5-(9.5)-10\end{array}$ & $\begin{array}{l}\text { I.-37.5-(75.8)-162.5 } \\
\text { II.-60-(75)-90 }\end{array}$ & $20-(21.9)-25$ & $\begin{array}{l}\text { Isla Cacaluta } \\
\text { (Oaxaca). } 4 \mathrm{~m} .\end{array}$ \\
\hline $\begin{array}{l}\text { Acarnus sabulum } \mathrm{n} \\
\text { MCNM 1.01/690 }\end{array}$ & $\begin{array}{l}\text { sp. } \\
150-(167.5)-190 \\
\times 2-(2.5)-3\end{array}$ & $\begin{array}{l}200-(263.5)-315 \\
\times 2.5-(7.5)-10\end{array}$ & $\begin{array}{l}\text { I.-100-(119.5)-150x } \\
3.75-(4.2)-5 \times \\
10-(13.5)-15 \\
\text { II.-67.5-(70.6)-80x } \\
2.5-(2.6)-3 \times 10-(10.8)-11.3\end{array}$ & $\begin{array}{l}\text { I.-11.5-(145.7)-165 } \\
\text { II.-25-(45.5)-80 } \\
\text { III.-30-(31.2)-35 }\end{array}$ & $10-(13.1)-15$ & $\begin{array}{l}\text { Bahía } \\
\text { Magdalena. } \\
\text { 3m. }\end{array}$ \\
\hline LEB-1126 & $\begin{array}{l}175-(217.8)-240 \\
\times 2.5-(3)-5\end{array}$ & $\begin{array}{l}260-(297)-330 \\
\times 5-(7)-10\end{array}$ & $\begin{array}{l}\text { I.- } 105-(122.8)-155 \times \\
\text { 3.75-(4.4)-7.5x } \\
11.3-(13.9)-15 \\
\text { II.-70-(77.5)-82x } \\
\text { 2-(2.5)-3x7.5-(9.2)-10 }\end{array}$ & $\begin{array}{l}\text { I.-82.5-(118.8)-137.5 } \\
\text { II.- 50-(79.6)-105 } \\
\text { III.- 25-(38)-60 }\end{array}$ & $10-(13.8)-16$ & $\begin{array}{l}\text { Puerto Peñasco } \\
\text { Sonora. } 4 \mathrm{~m} \text {. }\end{array}$ \\
\hline LEB-2017 & $\begin{array}{l}140-(168)-190 \\
\times 2-(2.5)-3\end{array}$ & $\begin{array}{l}200-(243.1)-325 \\
\times 2.5-(5.5)-10\end{array}$ & 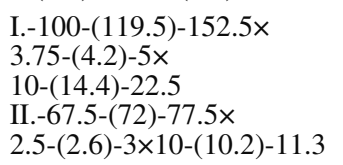 & $\begin{array}{l}\text { I.-87.5-(114.25)-167.5 } \\
\text { II.-25-(51.6)-80 } \\
\text { III.-30-(33.3)-35 }\end{array}$ & $10-(12.8)-15$ & $\begin{array}{l}\text { Bahía } \\
\text { Magdalena. } \\
\text { 3m. }\end{array}$ \\
\hline LEB-2018 & $\begin{array}{l}170-(186)-200 \\
\times 2-(2.5)-3\end{array}$ & $\begin{array}{l}240-(265.4)-290 \\
\times 5-(6.6)-7.5\end{array}$ & $\begin{array}{l}\text { I.- } 100-(112.8)-140 \times \\
2.5-(3.5)-5 \times \\
10-(14.3)-17.5 \\
\text { II.-60-(65.8)-80x } \\
2-(2.5)-3 \times 10-(10.8)-12.5\end{array}$ & $\begin{array}{l}\text { I.-120-(143.4)-165 } \\
\text { II.-25-(56.25)-115 } \\
\text { III.-30-(37)-40 }\end{array}$ & $10-(11.01)-15$ & $\begin{array}{l}\text { Bahía } \\
\text { Magdalena. } \\
3 \mathrm{~m} .\end{array}$ \\
\hline $\begin{array}{l}\text { A. deweerdtae } \\
\text { van Soest et al. } \\
\text { 1991* }\end{array}$ & $350 \times 3$ & $400 \times 6$ & $109-265 \times 5-8$ & $40-180$ & 15 & $\begin{array}{l}\text { Caribbean } \\
\text { Region. 20- } \\
100 \mathrm{~m} .\end{array}$ \\
\hline $\begin{array}{l}\text { A. toxeata Boury- } \\
\text { Esnault, 1973* }\end{array}$ & $213-472 \times 3-9$ & $12-16$ & $\begin{array}{l}\text { I. }-250-395 \times 3-9 \\
\text { II. }-56-162 \times 3\end{array}$ & $\begin{array}{l}\text { I.-28-265 } \\
\text { II.-500-945 }\end{array}$ & $12-16$ & $\begin{array}{l}\text { Brazil Coast. } \\
50 \mathrm{~m} .\end{array}$ \\
\hline $\begin{array}{l}\text { A. topsenti } \\
\text { Dendy, 1922* }\end{array}$ & $220 \times 3$ & $220-250 \times 7$ & $60-110 \times 4$ & $50-200$ & 11 & $\begin{array}{l}\text { Western Indian } \\
\text { Ocean. } 54 \mathrm{~m} .\end{array}$ \\
\hline $\begin{array}{l}\text { A. bergquistae } \\
\text { van Soest et al. } \\
1991^{*}\end{array}$ & $222-360 \times 3-4$ & $210-330 \times 9-16$ & $\begin{array}{l}\text { I. }-151-212 \times 5 \\
\text { II. }-58-109 \times 3\end{array}$ & $40-265$ & $11-13$ & $\begin{array}{l}\text { North Eastern } \\
\text { Australia. } \\
10 \mathrm{~m} .\end{array}$ \\
\hline $\begin{array}{l}\text { A. tortilis Topsent, } \\
1892^{*}\end{array}$ & $380 \times 5$ & $550 \times 10$ & $\begin{array}{l}\text { I. }-200 \times 5-6 \\
\text { II. }-100 \times 3.5-5\end{array}$ & $\begin{array}{l}\text { I.- }-20-150 \\
\text { II.- } 600\end{array}$ & 15 & $\begin{array}{l}\text { Mediterranean } \\
\text { and North East } \\
\text { Atlantic. } 91 \mathrm{~m} \text {. }\end{array}$ \\
\hline
\end{tabular}

and $<1 \mathrm{~mm}$ thick. Surface smooth. Oscula and ostia not observed. Consistency soft and flexible. Specimens are characterized by an amount of sediment in the choanosome. Colour in life red, whitish and translucent in preservation (Fig. 4C).

Skeleton. Ectosomal tylotes straight with microspined heads: 140-240×2-5 $\mu \mathrm{m}$ (Fig. 7A). Choanosomal styles slightly curved with smooth or microspined base: $200-330 \times 2.5-10 \mu \mathrm{m}$ (Fig. 7B). Cladotylotes microspined with four clades in two categories: I, long and thick (100-155×2.5-7.5 $\mu \mathrm{m})$, cladome 10-22.5 $\mu \mathrm{m}$ (Fig. 7C); II, short (60-82×2-3 $\mu \mathrm{m})$, cladome 7.5-12.5 $\mu \mathrm{m}$ (Fig. 7D). Toxas in three categories: I, accolada
(82.5-167.5 $\mu \mathrm{m})$ (Fig. 7E); II, wing-shaped (25-115 $\mu \mathrm{m})$ (Fig. 7F); III, uncommon oxhorn $(25-60 \mu \mathrm{m})$ (Fig. $7 \mathrm{G})$. Palmate isochelae with the alae reduced: 10-16 $\mu \mathrm{m}$ (Fig. 7H). The ectosomal skeleton is a dense layer of tylotes (35-60 $\mu \mathrm{m}$ thick). The choanosomal skeleton has a plumoreticulate structure formed by ascending fibre tracts (from 4-6 spicules). Interconnected by secondary paucispicular tracts (1-2 spicules). Cladotylotes are echinating the ascending fibres. Microscleres are dispersed with no special organization.

Etymology. Named "sabulum", which means sand in Latin, because this species incorporates sand grains in the choanosome. 


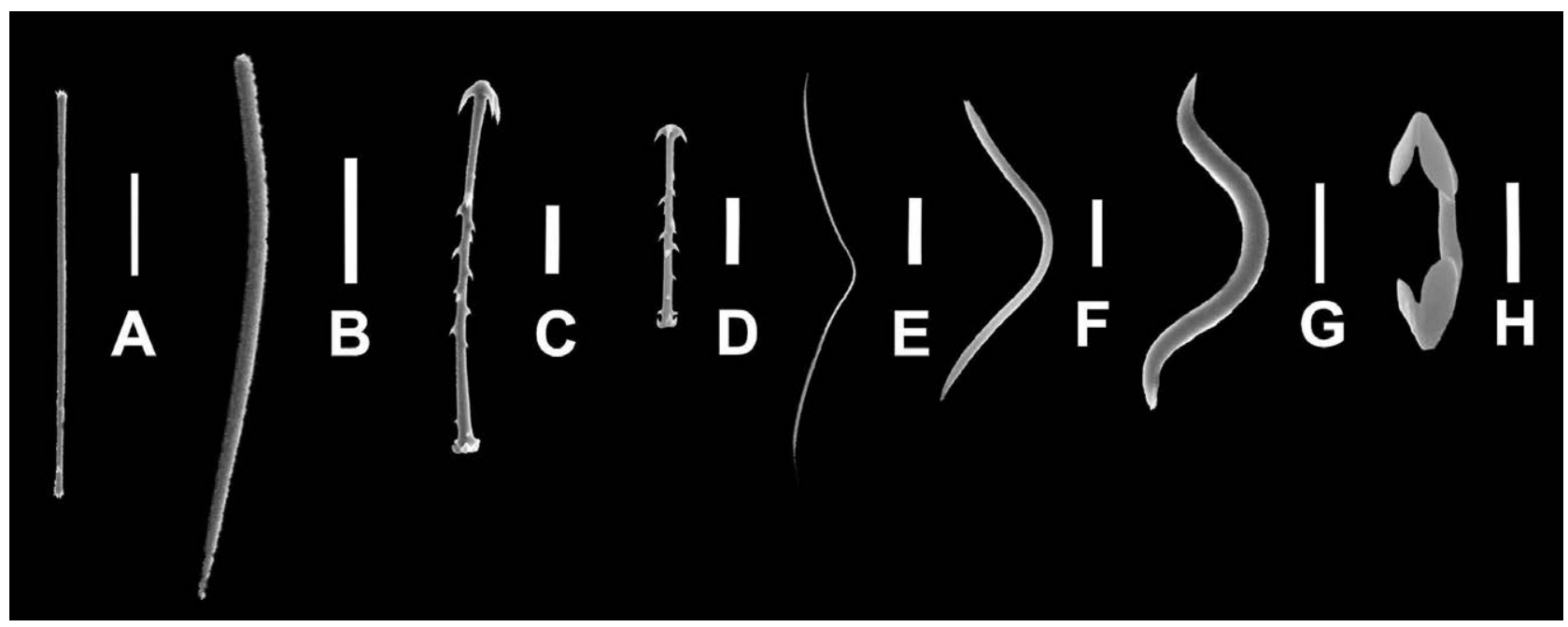

FIG. 7. - Acarnus sabulum n. sp. A, Ectosomal tylote with microspined heads. B, Choanosomal style. C, Cladoylote I microspined with four clades. D, Cladotylote II microspined with four clades. E, Accolada toxa. F, Wing-shaped toxa. G, Oxhorn toxa. H, Palmate isochela. Scale: A, C, $25 \mu \mathrm{m}$; B, $30 \mu \mathrm{m}$; D, E, F, $20 \mu \mathrm{m} ; \mathrm{G}, 15 \mu \mathrm{m} ; \mathrm{H}, 4 \mu \mathrm{m}$.

Remarks. Acarnus sabulum n. sp. is a subtidal sponge found in the Gulf of California. The only similar species is A. deweerdtae van Soest et al. 1991. This is an orange-red encrusting sponge from the Caribbean Region. The ectosomal tylotes and choanosomal styles are longer in A. deweerdtae than in Acarnus sabulum n. $\mathrm{sp}$. The remaining species of the "tortilis" group have some spicule element of different length than Acarnus sabulum n. sp. (Table 3).

\section{Genus Acheliderma Topsent, 1892 Acheliderma fulvum $\mathrm{n}$. sp. (Figs 4D and 8, Table 4)}

Material examined. Holotype, MCNM 1.01/691, 10/01/2011, Isla Venados (Mazatlán, Sinaloa), $6 \mathrm{~m}$ (2310'15',N 106²6'42,'W). Paratypes: 437-LEB-ICML-UNAM, 15/02/2002, Isla Pájaros (Mazatlan, Sinaloa), $10 \mathrm{~m}\left(23^{\circ} 15^{\prime} 29^{\prime}\right.$ 'N 106 $28^{\prime} 25^{\prime}$ ' W). 2041-LEBICML-UNAM, 10/01/2011, Isla Venados (Mazatlan, Sinaloa). 6 m $\left(23^{\circ} 10^{\prime} 15^{\prime \prime} \mathrm{N} 106^{\circ} 26^{\prime} 42^{\prime \prime} \mathrm{W}\right)$.

Description. Encrusting sponge from $3-7 \mathrm{~cm}$ long and 5-9 $\mathrm{mm}$ thick. Surface uneven with spicule projections (300-450 $\mu \mathrm{m}$ high) and fistules (5-10 mm high) evenly distributed. Each fistula with an apical oscule (300-500 $\mu \mathrm{m}$ in diameter). Ostia not observed. Consistency brittle and difficult to tear. Colour in life orange or pale yellow, transparent in preservation (Fig. 4D).

Skeleton. Ectosomal tylotes with microspined or smooth heads: 162.5-270×5-10 $\mu \mathrm{m}$ (Fig. 8A). Choanosomal styles with microspined base: $150-500 \times 5-10$ $\mu \mathrm{m}$ (Fig. 8B). Echinating acanthostyles covered with prominent spines: $62.5-125 \times 2.5-5 \mu \mathrm{m}$ (Fig. 8C). Toxas V-shaped: 40-85 $\mu \mathrm{m}$ (Fig. 8D). Microxeas diamondshaped: $25-75 \mu \mathrm{m}$ (Fig. 8E). The ectosomal skeleton is a dense layer of tylotes (30-40 $\mu \mathrm{m}$ thick). The choanosomal skeleton has a plumose arrangement of ascending primary multispicular fibres made of the styles
(50-60 $\mu \mathrm{m}$ thick). Interconnected by secondary pauci-, uni- or bispicular fibres (10-30 $\mu \mathrm{m}$ thick). Acanthostyles are echinating the primary fibres. Sand is found in the choanosome. Microxeas and toxas are dispersed with no special organization.

Etymology. Named "fulvum", which means yellow in Latin.

Remarks. Acheliderma fulvum n. sp. is a subtidal species found in the Gulf of California. Currently, there are four species assigned to the genus: A. lemniscatum Topsent, 1892 (Mediterranean Sea), A. fistulatum (Dendy, 1896) (South Australia), A. planum (Topsent, 1927) (Azores) and A. lisannae van Soest, Zea and Kielman, 1994 (Caribbean, Colombia). A. lemniscatum Topsent, 1892 is a yellow encrusting sponge with small fistulae on the surface. It has tylotes with microspined heads (250-270 $\mu \mathrm{m})$, styles with microspined base (420-450 $\mu \mathrm{m})$, acanthostyles $(80-175 \mu \mathrm{m})$, toxas $(120$ $\mu \mathrm{m})$ and microxeas $(60-70 \mu \mathrm{m})$. The acanthostyles and toxas are shorter in Acheliderma fulvum n. sp. than in A. lemniscatum. A. planum (Topsent, 1927) is a thinly encrusting sponge. It has tylotes with microspined heads (265-315 $\mu \mathrm{m})$, acanthostyles (105-455 $\mu \mathrm{m})$, toxas $(125 \mu \mathrm{m})$ and microxeas $(30-37 \mu \mathrm{m})$. The toxas are shorter and the microxeas longer in Acheliderma fulvum n. sp. than in A. planum. A. lisannae van Soest et al. 1994 is a small fistula-shaped sponge described in the Colombian Caribbean. It has tylotes with microspined heads (243-348 $\mu \mathrm{m})$, styles with microspined base (399-481 $\mu \mathrm{m})$, acanthostyles (67-101 $\mu \mathrm{m})$, toxas (101-136 $\mu \mathrm{m})$ and microxeas in two categories: I) 36$52 \mu \mathrm{m}$ and II) 19-28 $\mu \mathrm{m}$. The toxas are longer in $A$. lisannae than in Acheliderma fulvum n. sp. Another species assigned to this genus in the western Pacific is A. fistulatum (Dendy, 1896). This is a yellow massive sponge with fistulae on the surface. The original 


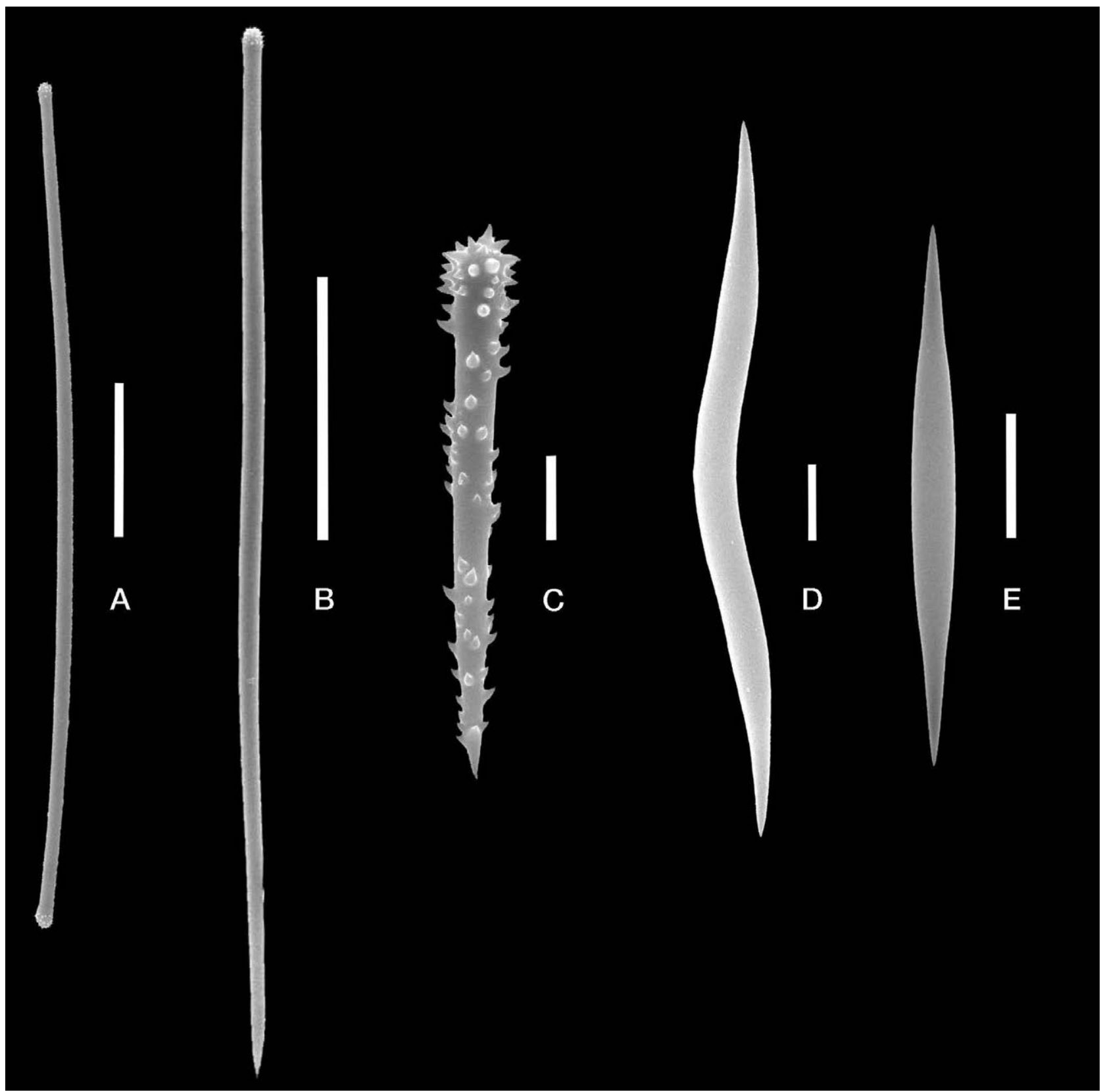

FIG. 8. - Acheliderma fulvum n. sp. A, Ectosomal tylote with microspined heads. B, Choanosomal style with microspined base. C, Echinating acanthostyle. D, V-shaped toxa. E, Microxea. Scale: A, $40 \mu \mathrm{m}$; B, $70 \mu \mathrm{m}$; C, $10 \mu \mathrm{m}$; D, $7.5 \mu \mathrm{m} ; \mathrm{E}, 2.5$.

description reported tylostyles $(540 \mu \mathrm{m})$, acanthostyles $(70 \mu \mathrm{m})$, toxas $(130-300 \mu \mathrm{m})$ and microxeas $(46 \mu \mathrm{m})$. The toxas are shorter in Acheliderma fulvum n. sp. than in A. fistulatum.

The genus Acheliderma: The genus Acheliderma was created by Topsent (1892) for a species with raphides, later denominated microxeas. The original description includes choanosomal styles, tylotes, acanthostyles and toxas. Topsent (1927) erected the genus Astylinifer for A. planus, a species described with acanthostyles in one category. However, there is a difference between the principal choanosomal styles (acanthostyles) with the echinating acanthostyles. Although Topsent (1927) did not recognize these dissimilarities, this is specific of the genus Acheliderma. We agree with the synonymy of these two genera proposed by van Soest et al. (1994) and Hooper (2002a). The genus Fusifer was created by Dendy (1896) for the type species $F$. fistulatum described from the southern coast of Australia. The original description reported tylostyles, acanthostyles, toxas and microxeas. van Soest et al. (1994) synonymized this genus with Acheliderma because they shared the presence of microxeas in the skeleton. However, if we consider the presence of tylotes a diagnostic feature in the allocation of species of the family Acarnidae, $F$. fistulatum lacks this spicule. van Soest et al. (1994) 
688 - J.M. Aguilar-Camacho et al.

TABLE 4. - Spicule measurements of Acheliderma fulvum n. sp. Values are expressed in minimum-average-maximum ( $\mu$ m).

\begin{tabular}{|c|c|c|c|c|c|}
\hline Material examined & $\begin{array}{c}\text { Tylotes } \\
\text { (length } \times \text { width) }\end{array}$ & $\begin{array}{c}\text { Styles with } \\
\text { microspined base } \\
\text { (length } \times \text { width })\end{array}$ & $\begin{array}{l}\text { Acanthostyles } \\
\text { (length } \times \text { width) }\end{array}$ & $\begin{array}{l}\text { Toxas } \\
\text { (length) }\end{array}$ & $\begin{array}{l}\text { Microxeas } \\
\text { (length) }\end{array}$ \\
\hline MCNM 1.01/691 & $\begin{array}{l}175-(205)-260.5 \times \\
2.5-(4.3)-7.5\end{array}$ & $\begin{array}{l}210-(364.4)-480 \times \\
5-(7.1)-10\end{array}$ & $\begin{array}{l}72.5-(89.2)-115 \times \\
2.5-(2.9)-5\end{array}$ & $45-(65.6)-85$ & $25-(51.1)-65$ \\
\hline LEB-437 & $\begin{array}{l}162.5-(217.5)-255 \times \\
2.5-(2.9)-7.5\end{array}$ & $\begin{array}{l}150-(302.4)-500 \times \\
5-(6.7)-7.5\end{array}$ & $\begin{array}{l}62.5-(78.3)-125 x \\
2.5-(2.6)-5\end{array}$ & $50-(61.7)-85$ & $30-(40.5)-45$ \\
\hline LEB-2071 & $\begin{array}{l}210-(202.5)-270 \times \\
2.5-(3.4)-7.5\end{array}$ & $\begin{array}{l}365-(395.8)-465 \times \\
5-(8.2)-10\end{array}$ & $\begin{array}{l}75-(85.2)-100 \times \\
2.5-(5.6)-7.5\end{array}$ & $40-(48.5)-70$ & $25-(54.5)-75$ \\
\hline
\end{tabular}

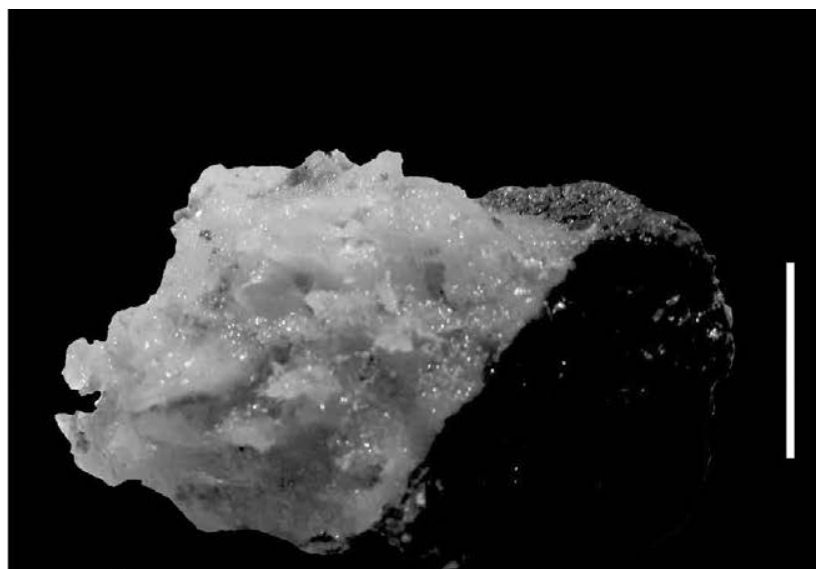

A

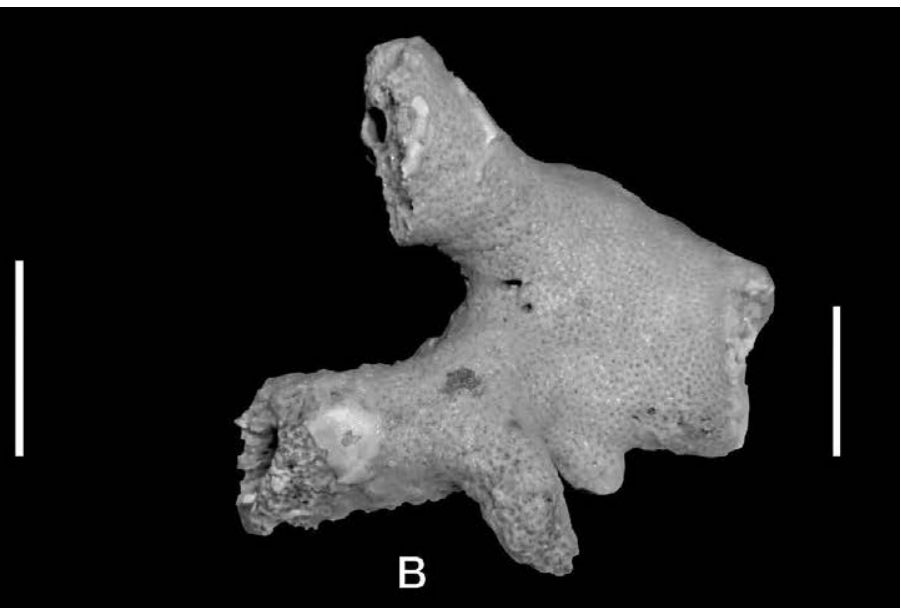

C

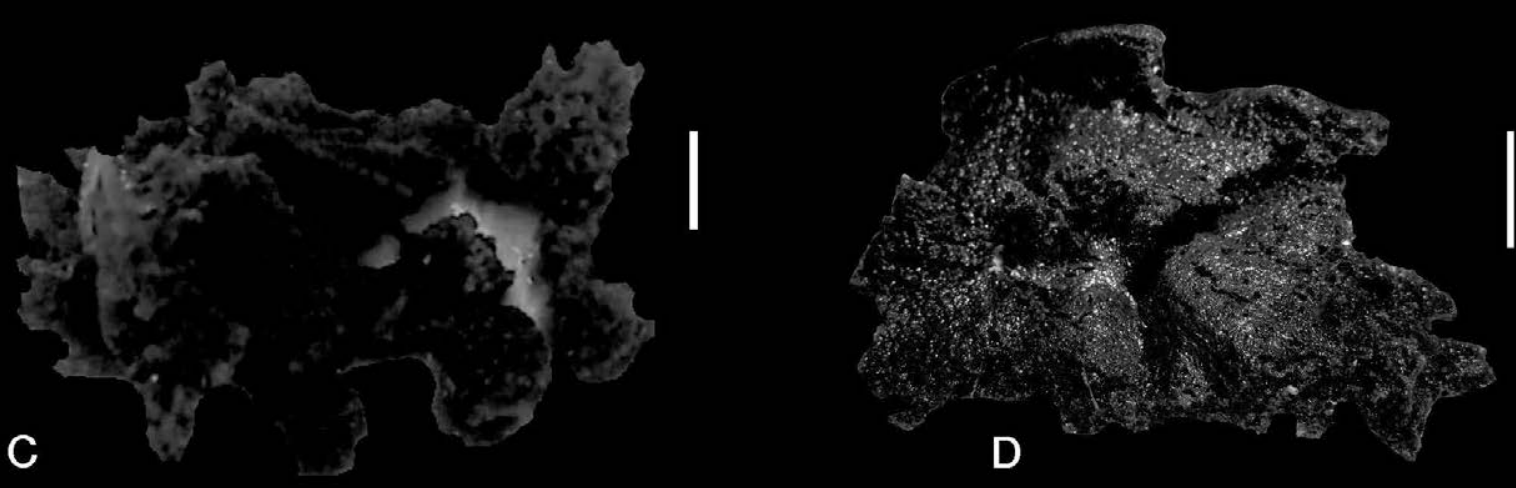

FIG. 9. - A, Megaciella microtoxa (Dickinson, 1945). Fragment of the neotype (AHF 556-36). B, Megaciella toxispinosa n. sp. Preserved specimen growing over coral fragment. C, Iophon indentatum Wilson, 1904. Fragment of Allan Hancock Pacific Expedition (AHF 560-36).

$\mathrm{D}$, Iophon bipocillum $\mathrm{n}$. sp. Fragment of a preserved specimen. Scale: A, D, $2 \mu \mathrm{m}$; B, $3 \mu \mathrm{m} ; \mathrm{C}, 1 \mu \mathrm{m}$.

suggested that the tylotes have been replaced by sand, because of the presence of foreign material embedded in the skeleton. We think that this species has more affinities with the family Microcionidae, because it bears tylostyles, acanthostyles, toxas and microxeas. The presence of microxeas has been reported for species belonging to the family Microcionidae such as Clathria (Clathria) microxa Desqueyroux, 1972 and C. (Microciona) microxea (Vacelet and Vasseur, 1971) (this species lacks acanthostyles which is consider a diagnostic feature in the subgenus Microciona sensu Hooper, 1996). The ectosomal skeleton in $F$. fistulatum is a tangential layer of tylostyles. The choanosomal skeleton is formed by ascending primary tracts made of tylostyles and sand grains. Acanthostyles are echinating externally the tracts (Dendy, 1896).

Currently, in the family Microcionidae there are three genera, Clathria (Wilsonella) Carter, 1885, 


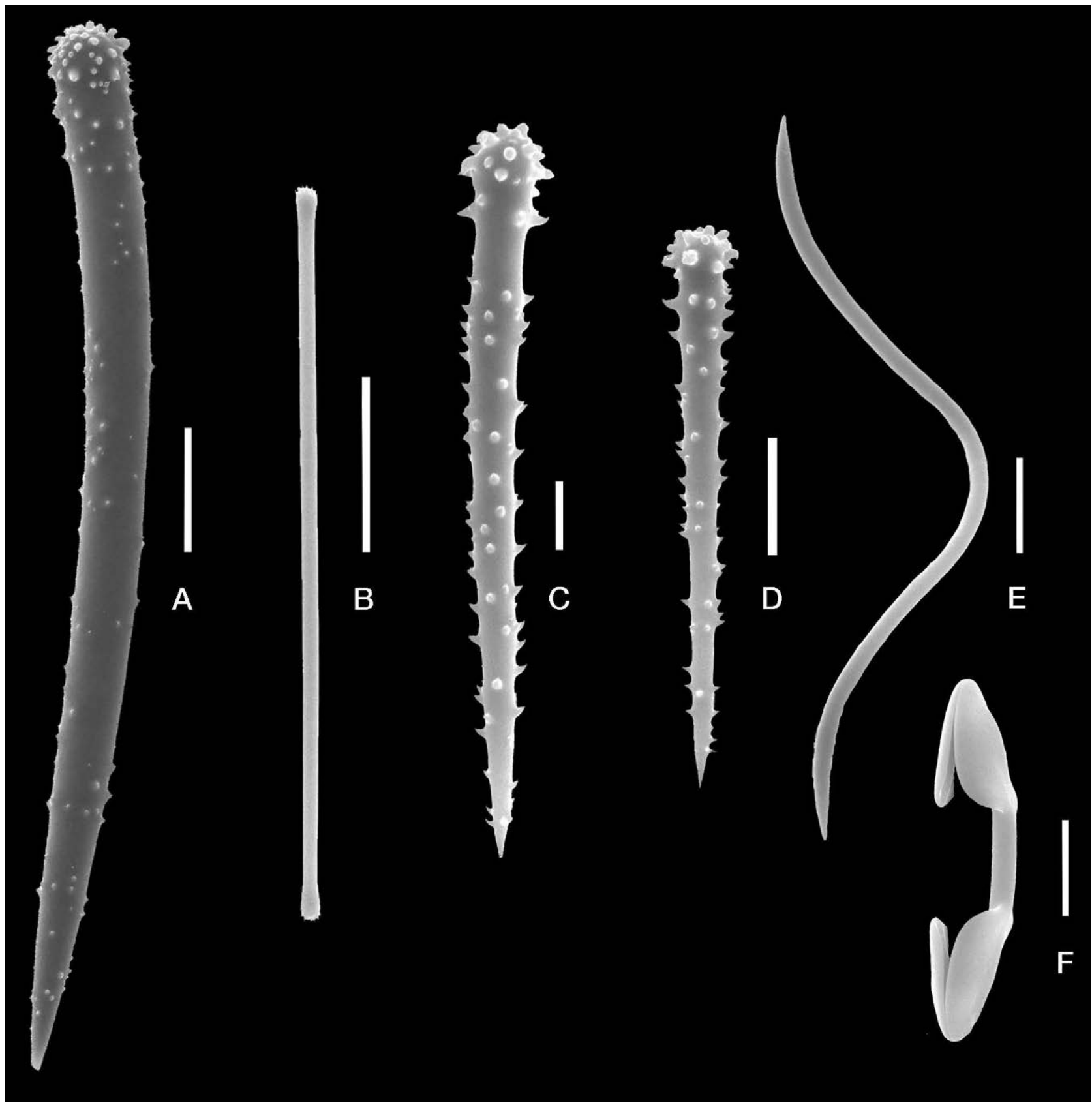

FIG. 10. - Megaciella microtoxa (Dickinson, 1945). A, Choanosomal acanthostyle. B, Ectosomal tylote with microspined heads. C, D, Echinating acanthostyle. E, Wing-shaped toxa. F, Palmate isochela. Scale: A, $40 \mu \mathrm{m}$; B, $60 \mu \mathrm{m}$; C, D, E, $15 \mu \mathrm{m} ; \mathrm{F}, 3.5 \mu \mathrm{m}$.

Echinochalina Thiele, 1903 and Holopsamma Carter, 1885, which incorporate sand grains in the skeleton (Hooper 1996). However, they have some morphological differences from the genus Fusifer. Clathria (Wilsonella) has styles, subtylostyles, acanthostyles, palmate isochelae and toxas. The ectosomal skeleton is made of sand grains and the choanosomal skeleton is reticulate (Hooper 2002b). The Fusifer species has styles, acanthostyles, microxeas and toxas. The ectosomal skeleton is a dense layer of tylostyles and the choanosomal skeleton is made of ascending primary tracts echinating by acanthostyles. The palmate iso- chelae are lacking in the Fusifer species, but this may be a homoplasic character as in many species of the genus Clathria, in which the presence or absence of palmate isochelae is not a diagnostic feature in the allocation of a specific subgenera (Hooper 1996). The difference between these two genera is the ectosomal skeleton: made of sand grains in Clathria (Wilsonella) and a tangential layer of tylostyles in Fusifer. The genera Echinochalina and Holopsamma have a choanosomal skeleton formed by ascending primary fibres of sand grains, megascleres are monactinal spicules and microscleres include toxas and palmate 
isochelae. No species belonging to these two genera have acanthostyles in the skeleton, while the Fusifer species bears acanthostyles and microxeas. Taking into account all these morphological differences, we consider that this genus is not a junior synonym of Acheliderma. A further morphological analysis should be undertaken to corroborate the validity of the genus Fusifer.

Genus Megaciella Hallman, 1920

Megaciella microtoxa (Dickinson, 1945)

(Figs 9A and 10, Table 5)

Myxichela microtoxa Dickinson, 1945:17-18.

Megaciella microtoxa Desqueyroux-Faúndez and van Soest, 1996:27.

Material examined. Neotype, LACM \# 1936-70, 08/03/1936, North of Partida Island, Gulf of California (MEX), $18 \mathrm{~m}\left(28^{\circ} 5472\right.$ "N $113^{\circ} 03.8^{\prime \prime W}$ ). R/V VELERO III. AHF 556-36 (Dickinson, 1945).

Description. Cushion-shaped sponge growing on a flat boulder, size from $5 \mathrm{~cm}$ long and $2 \mathrm{~cm}$ thick. Surface smooth. Oscula not observed. Ostia circular to oval shaped (100-150 um long) and evenly distributed. Consistency brittle and difficult to tear. Colour in preservation pale yellow (Fig. 9A).

Skeleton. Choanosomal acanthostyles thick with short spines: $360-540 \times 17.5-25 \mu \mathrm{m}$ (Fig. 10A). Ectosomal tylotes with microspined heads: $190-250 \times 2.5-5$ $\mu \mathrm{m}$ (Fig. 10B). Echinating acanthostyles straight, with prominent spines: 85-215×2.5-7.5 $\mu \mathrm{m}$ (Fig. 10C, D). Toxas wing-shaped with a pronounced curvature: 50-140 $\mu \mathrm{m}$ (Fig. 10E). Palmate isochelae with the alae fused to the shaft: $12.5-15 \mu \mathrm{m}$ (Fig. 10F). The ectosomal skeleton is a thin layer of tylotes (20-40 $\mu \mathrm{m}$ thick). The choanosomal skeleton is an isotropic reticulum formed by ascending multispicular primary fibres made of the principal acanthostyles (100-125 $\mu \mathrm{m}$ wide). Interconnected by secondary bi- o multispicular fibres (50-75 $\mu \mathrm{m}$ wide). Acanthostyles are echinating the primary fibres. Microscleres are dispersed with no special organization.

Remarks. The holotype of Megaciella microtoxa (Dickinson, 1945) was lost. However, we examined specimens of this species collected in the Allan Hancock Pacific Expedition whose spicule measurements match with the original description. Therefore, we propose to establish a neotype for this species. Dickinson (1945) did not report the presence of two categories of acanthostyles which are present in the neotype.

Megaciella toxispinosa $\mathrm{n}$. sp.

(Figs 9B and 11, Table 5)

Material examined. Holotype, MCNM 1.01/692, 24/09/2010, Cerro

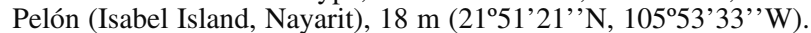
Paratypes: 1484-LEB-ICML-UNAM, 12/03/2007, Cabo Pulmo (South Baja California), $7 \mathrm{~m}$ (23 $\left.26^{\prime} 24^{\prime \prime} \mathrm{N} 109^{\circ} 24^{\prime} 43^{\prime \prime} \mathrm{W}\right)$. 1975-LEB-ICML-UNAM, 24/09/2010, Cerro Pelón (Isabel Island, Nayarit), 18 m (2151'21',N 105'53'33', W).

Description. Thinly-encrusting sponge growing on corals and stones, size 6-8 $\mathrm{cm}$ long and 5-10 mm thick. Oscula not observed. Surface hispid with ostia circular to oval shaped (600-800 $\mu \mathrm{m}$ long) and spicule projections (250-450 $\mu \mathrm{m}$ height), evenly distributed. Consistency brittle and easy to tear. Colour in life orange, pale in preservation (Fig. 9B).

Skeleton. Ectosomal tylotes straight or curved with microspined heads: 160-215×2.5 $\mu \mathrm{m}$ (Fig. 11A). Choanosomal acanthostyles straight or curved covered with prominent spines: $150-315 \times 2.5-5 \mu \mathrm{m}$ (Fig. 11B). Echi-

TABle 5. - Comparative table data of spicule categories for the Megaciella species from the Mexican Pacific. Values are expressed in minimum-average-maximum $(\mu \mathrm{m})$.* Spicules measurements from the original description.

\begin{tabular}{|c|c|c|c|c|c|}
\hline $\begin{array}{l}\text { Material } \\
\text { Examined }\end{array}$ & $\begin{array}{c}\text { Tylotes } \\
(\text { Length } \times \text { Width })\end{array}$ & $\begin{array}{l}\text { Acanthostyles } \\
\text { (Length } \times \text { Width) }\end{array}$ & $\begin{array}{c}\text { Toxas } \\
\text { (Length) }\end{array}$ & $\begin{array}{l}\text { Palmate isochelae } \\
\text { (Length) }\end{array}$ & Locality and Depth \\
\hline \multicolumn{6}{|c|}{ Megaciella microtoxa (Dickinson, 1945) } \\
\hline AHF-55636 & $\begin{array}{l}190-(221.1)-250 \times \\
2.5-(3.1)-5\end{array}$ & $\begin{array}{l}\text { I.- 360-(460.2)-540x } \\
\text { 17.5-(22.5)-25 } \\
\text { II.- } 85-(150.9)-215 \times \\
2.5-(4.1)-7.5\end{array}$ & $50-(98.4)-140$ & $12.5-(12.8)-15$ & $\begin{array}{l}\text { North of Partida Island, } \\
\text { Gulf of California. } 18 \mathrm{~m} .\end{array}$ \\
\hline $\begin{array}{l}\text { AHF-55536* } \\
\text { (Lost) }\end{array}$ & $190 \times 4$ & $333 \times 20$ & 135 & 15 & $\begin{array}{l}\text { Angel de la Guarda, Island. } \\
\text { Gulf of California. } 40 \mathrm{~m} \text {. }\end{array}$ \\
\hline \multicolumn{6}{|c|}{ Megaciella toxispinosa $\mathrm{n} . \mathrm{sp}$. } \\
\hline MCNM 1.01/692 & $\begin{array}{l}175-(188.1)-210 \times \\
2.5-(2.5)-2.5\end{array}$ & $\begin{array}{l}\text { I.- } 185-(221.5)-300 \times \\
2.5-(3.3)-5 \\
\text { II.- 60-(72.5)-85x } \\
2.5-(2.7)-3.5\end{array}$ & $\begin{array}{l}\text { I.-35-(43.2)-60 } \\
\text { II.-3-(5.8)-7.5 }\end{array}$ & $12.5-(13.2)-15$ & Isla Isabel, Nayarit. $15 \mathrm{~m}$. \\
\hline LEB-1484 & $\begin{array}{l}160-(179.2)-205 x \\
2.5-(3.1)-3.75\end{array}$ & $\begin{array}{l}\text { I.- } 150-(213.3)-280 \times \\
2.5-(6.2)-7.5 \\
\text { II.- 55-(77.9)-105x } \\
\text { 2.5-(3.1)-3.5 }\end{array}$ & $\begin{array}{l}\text { I.-35-(42.8)- } 45 . \\
\text { II.-5-(6.1)-7.5 }\end{array}$ & $10-(13.3)-15$ & Cabo Pulmo, Baja Sur. $7 \mathrm{~m}$. \\
\hline LEB-1975 & $\begin{array}{l}170-(182.5)-215 x \\
2.5-(2.5)-2.5\end{array}$ & $\begin{array}{l}\text { I.- } 205-(237.5)-315 \times \\
2.5-(3.15)-5 \\
\text { II.- 60-(72.5)-90x } \\
\text { 2.5-(2.8)-3.5 }\end{array}$ & $\begin{array}{l}\text { I.-35-(45.5)-60. } \\
\text { II.-3-(5.6)-7.5 }\end{array}$ & $12.5-(14.3)-17.5$ & Isla Isabel, Nayarit. $15 \mathrm{~m}$. \\
\hline
\end{tabular}




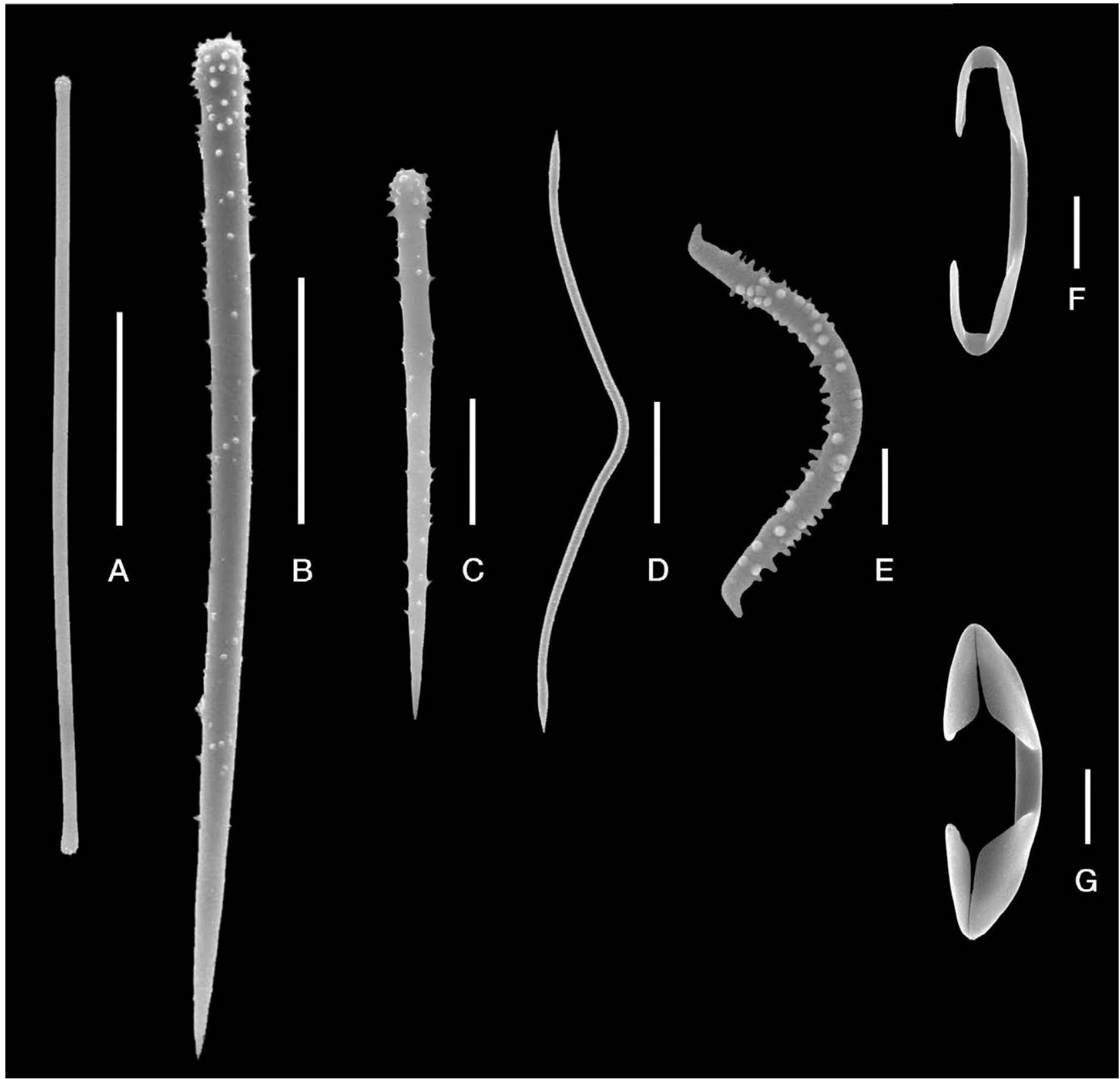

Fig. 11. - Megaciella toxispinosa n. sp. A, Ectosomal tylote with microspined heads. B, Choanosomal acanthostyle. C, Echinating acanthostyle. D, Wing-shaped toxa. E, Microspined toxa. F, Palmate isochela with the alae reduced. G, Palmate isochela with the alae fused to the shaft. Scale: A, $50 \mu \mathrm{m}$; B, $70 \mu \mathrm{m}$; C, $20 \mu \mathrm{m}$; D, $7.5 \mu \mathrm{m}$; E, $1 \mu \mathrm{m}$; F, $2.5 \mu \mathrm{m}$; G, $3.5 \mu \mathrm{m}$.

nating acanthostyles curved or straight, with prominent spines: $55-105 \times 2.5-3.5 \mu \mathrm{m}$ (Fig. 11C). Toxas in two sizes: I) wing-shaped with a pronounced curvature (35$60 \mu \mathrm{m})$ (Fig. 11D); II) oxhorn microspined (3-10 $\mu \mathrm{m})$ (Fig. 11E). Palmate isochelae in two forms: I, with the alae reduced (12.5-15 $\mu \mathrm{m})$ (Fig. 11F); II, with the alae fused to the shaft $(12.5-17.5 \mu \mathrm{m})$ (Fig. 11G). The ectosomal skeleton is a dense layer of tylotes (60-120 $\mu \mathrm{m}$ thick). The choanosomal skeleton is plumose formed by ascending primary multispicular tracts $(35-60 \mu \mathrm{m}$ wide) made of the choanosomal acanthostyles. Acanthostyles II are echinating the primary fibres. Microscleres are dispersed with no special organization.
Etymology. Named "toxispinosa" because the toxas II are microspined.

Remarks. Megaciella toxispinosa n. sp. is a subtidal species from the Gulf of California. Megaciella species with acanthostyles as choanosomal megascleres are $M$. microtoxa (Dickinson, 1945), M. incrustans van Soest, 2009 and M. tawiensis (Wilson, 1925) (Table 5). M. microtoxa (Dickinson, 1945) is a massive sponge described from the Mexican Pacific. The acanthostyles and toxas are shorter in Megaciella toxispinosa n. sp. than in M. microtoxa (see above). Megaciella incrustans van Soest, 2009 is a red encrusting sponge 
described from Santa Martha (Colombia). It has tylotes with microspined heads $(237-309 \times 2-3.5 \mu \mathrm{m})$, acantho-

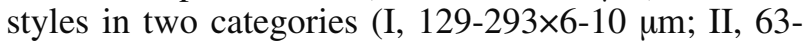
$93 \times 3.5-7 \mu \mathrm{m})$ and palmate isochelae $(9-14 \mu \mathrm{m})$. The tylotes are shorter in Megaciella toxispinosa $\mathrm{n}$. sp. than in $M$. incrustans. In addition, $M$. incrustans lacks toxas while in $M$. toxispinosa $\mathrm{n}$. sp. this spicule is present.

Megaciella tawiensis (Wilson, 1925) is a laminate sponge described from the Sulu archipelago (western Pacific). It has ectosomal tylotes $(150-280 \mu \mathrm{m})$, acanthostyles $(280-350 \mu \mathrm{m})$, toxas $(150-350 \mu \mathrm{m})$ and palmate isochelae $(14-20 \mu \mathrm{m})$. The toxas and palmate isochelae are longer in M. tawiensis than in Megaciella toxispinosa n. sp. Recently, Lee et al. (2007) described an unidentified Megaciella species from deep waters of California. This is a thick encrusting sponge, with acanthostyles in three categories (I, 145-339 $\times 12-17$

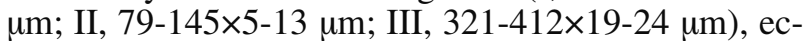
tosomal subtylotes with microspined heads $(64-280 \times 4-$ $7 \mu \mathrm{m})$, palmate isochelae $(16-25 \mu \mathrm{m})$ and toxas wingshaped in two categories (I, with a high arch 7-193 $\mu \mathrm{m}$; II, with a low arch, 8-13 $\mu \mathrm{m})$. M. toxispinosa n. sp. has two categories of acanthostyles shorter than those from California (Table 5).

The genus Megaciella: Hallman (1920) created the genus Megaciella for Megaciella spinosa (Ridley and Dendy, 1886). This species has choanosomal styles, ectosomal tylotes with microspined heads, palmate isochelae and non-spinolous toxas. De Laubenfels (1936) created the genus Myxichela for Lissodendoryx tawiensis Wilson, 1925. This species bears ectosomal tylotes, choanosomal acanthostyles, palmate isochelae and toxas. Hooper (2002a) synonymized the genus Megaciella with Myxichela because of the presence of ectosomal tylotes and choanosomal monactinal spicules. According to van Soest et al. (2012), there are currently 12 species assigned to this genus. Based on the literature, there are species with styles as choanosomal megascleres and others with choanosomal acanthostyles. Also, there are a few species bearing echinating acanthostyles, such as $M$. toxispinosa n.sp. Koltun (1959) described two new species under the genus Myxichela from the Okhotsk Sea (Russia). These two species bear toxas and arcuate chelae as microscleres
(M. ochotensis and M. spirinae). According to Hajdu et al. (1994), the suborder Microcionina is characterized by sponges with palmate isochelae and toxas (lacking sigmas). The suborder Myxillina is characterized by sponges with arcuate-anchorate chelae with more than three teeth and sigmas (lacking toxas). M. ochotensis (Koltun, 1959) and M. spirinae (Koltun, 1959) share two diagnostic features of two suborders (arcuate chelae and toxas). However, the combination of these two microscleres has been reported before. Bakus (1966) created the genus Coelosphaericon for the type species C. hatchi Bakus, 1966 from the North Eastern Pacific. It has tylotes with smooth heads, arcuate chelae and toxas. At this time, Coelosphaericon is a junior synonym of Coelosphaera (Myxillina, Coelosphaeridae) (van Soest et al. 2012). A further morphological examination should be undertaken to see the validity of all the species currently assigned to the genus Megaciella.

Genus Iophon Gray, 1867

Iophon indentatum Wilson, 1904

(Figs 9C and 12, Table 6)

Iophon indentatum Wilson, 1904: 151; Dickinson, 1945: 151; Desqueyroux-Faúndez and van Soest, 1996:15.

Syntype: U.S.N.M. 8277, Albatross Stn, 3405 0057'S 89³8'W (Not examined).

Material examined. D-30, 09/03/1936, Partida Island, Gulf of California (MEX) $73 \mathrm{~m}\left(28^{\circ} 54.72^{\prime} \mathrm{N} 113^{\circ} 03.8^{\prime \prime W}\right)$. R/V VELERO III. AHF 560-36 (Dickinson 1945).

Description: Massive or lobulated sponge size from 2-4 $\mathrm{cm}$ long and $2 \mathrm{~cm}$ thick. Surface rough with small fistulae (2-4 cm height). Ostia circular (300-600 $\mu \mathrm{m}$ long) and evenly distributed. Each fistula with an apical oscule (6-12 mm long). Consistency elastic and flexible. Colour preserved light brown (Fig. 9C).

Skeleton. Ectosomal tylotes with microspined heads: 230-280×5-7.5 $\mu \mathrm{m}$ (Fig. 12A). Choanosomal acanthostyles covered with short spines: $270-315 \times 5-15$ $\mu \mathrm{m}$ (Fig. 12B). Palmate anisochelae with a protuberance on the lower ala: 10-17.5 $\mu \mathrm{m}$ (Fig. 12C). Bipocilla multidentate: 10-12.5 $\mu \mathrm{m}$ (Fig. 12D). The ectosomal

TABLE 6. - Comparative table of spicule categories of Iophon indentatum Wilson, 1904 and Iophon lamella Wilson, 1904.Values are expressed in minimum-average-maximum $(\mu \mathrm{m}) . *$ Spicules measurements from the original description.

\begin{tabular}{|c|c|c|c|c|}
\hline Species & $\begin{array}{l}\text { Acanthostyles } \\
\text { (length } \times \text { width) }\end{array}$ & $\begin{array}{c}\text { Tylotes } \\
\text { (length } \times \text { width) }\end{array}$ & $\begin{array}{l}\text { Palmate anisochelae } \\
\text { (length) }\end{array}$ & $\begin{array}{l}\text { Bipocilla } \\
\text { (length) }\end{array}$ \\
\hline $\begin{array}{l}\text { I. indentatum } \\
\text { AHF 560-36 }\end{array}$ & $\begin{array}{c}270-(296.3)-315 \times \\
5-(10.5)-15\end{array}$ & $\begin{array}{l}230-(258.8)-280 \times \\
5-(5.9)-7.5\end{array}$ & $10-(15.3)-17.5$ & $10-(11.4)-12.5$ \\
\hline I. indentatum Wilson, $1904^{*}$ & $220 \times 14-16$ & $220 \times 8$ & 14 & 8 \\
\hline $\begin{array}{l}\text { I. indentatum sensu Desqueyroux- } \\
\text { Faundez and van Soest, 1996* }\end{array}$ & $199-234 \times 16$ & $207-220 \times 7-8$ & 16 & 8 \\
\hline $\begin{array}{l}\text { Iophon lamella sensu Desqueyroux- } \\
\text { Faundez and van Soest, 1996* }\end{array}$ & $210-250 \times 10-16$ & $202-240 \times 6-8$ & $\begin{array}{l}\text { I. }-10-16 \\
\text { II. }-20-29\end{array}$ & $8-16$ \\
\hline $\begin{array}{l}\text { I. chelifer var. californiana } \\
\text { de Laubenfels, } 1932 *\end{array}$ & $234-260 \times 12$ & $200-241 \times 7-8$ & $\begin{array}{l}\text { I. }-12-23 \\
\text { II. }-27-35\end{array}$ & $12-20$ \\
\hline $\begin{array}{l}\text { Burtonella melanokhenia } \\
\text { de Laubenfels, } 1928\end{array}$ & $270-304 \times 16-20$ & $222-253 \times 7-8$ & $\begin{array}{l}\text { I. }-12-16 \\
\text { II.-20-25 }\end{array}$ & $12-16$ \\
\hline
\end{tabular}




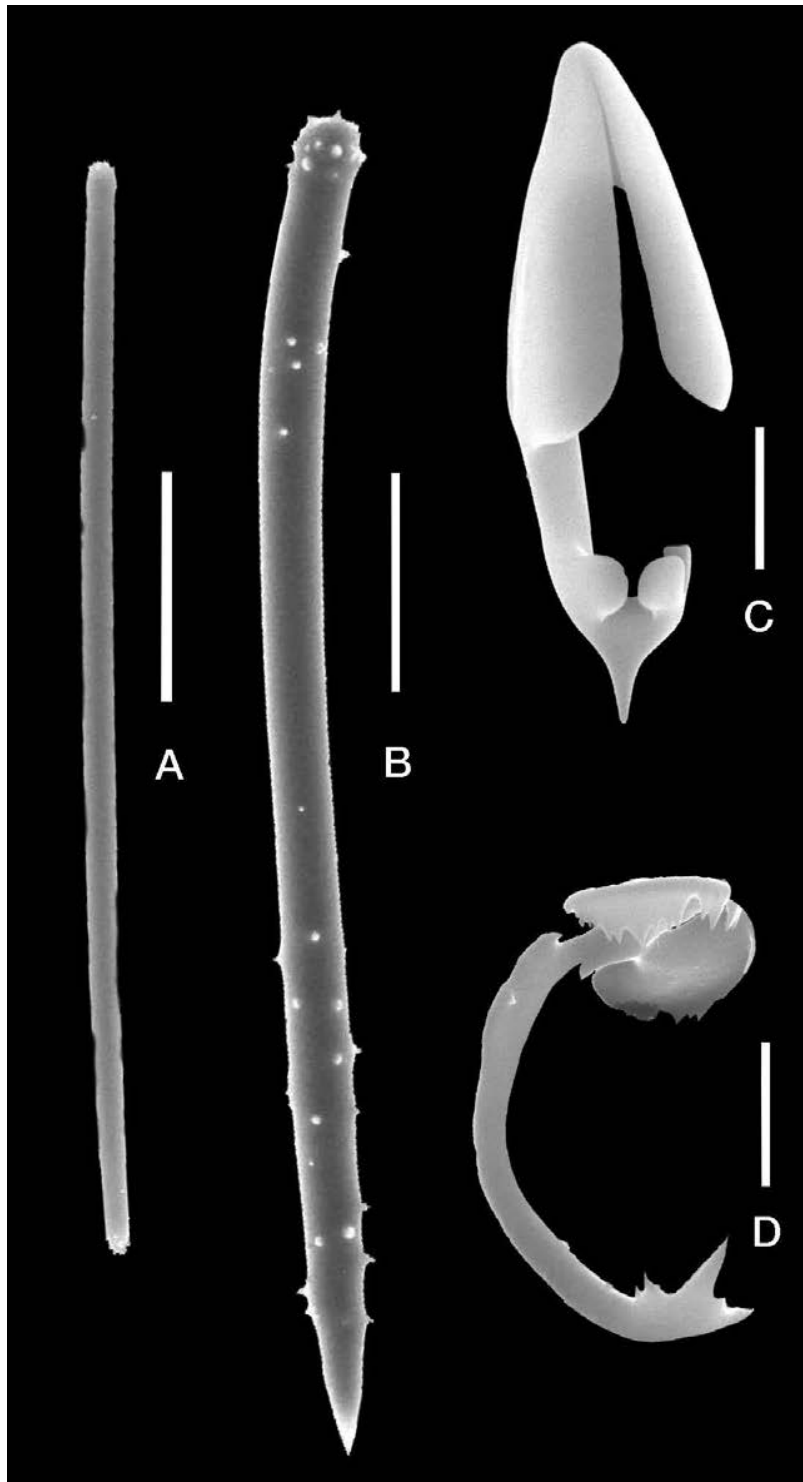

FIG. 12. - Iophon indentatum Wilson, 1904. A, Ectosomal tylote with microspined heads. B, Choanosomal acanthostyle. C, Anisochela. D, Bipocillae. Scale: A, $40 \mu \mathrm{m} ; \mathrm{B}, 30 \mu \mathrm{m}$; C, $3 \mu \mathrm{m}$; D, $5 \mu \mathrm{m}$.

skeleton is a tangential layer of tylotes (20-30 $\mu \mathrm{m}$ thick). The choanosomal skeleton is an isotropic reticulum formed by ascendant multispicular primary fibres (80-150 $\mu \mathrm{m}$ wide), interconnected by multispicular secondary fibres (20-45 $\mu \mathrm{m}$ wide). The organization forms quadrangular meshes (20-35 $\mu \mathrm{m}$ wide). The microscleres are dispersed with no special organization.

Remarks. Iophon indentatum Wilson, 1904 was originally described from the continental shelf of the Galapagos Islands. Dickinson (1945) reported this species from the Gulf of California. Specimens from the Mexican Pacific have the tylotes and the acanthostyles longer than those described by Wilson (1904) (Table 6). Dickinson (1945) considered that I. indentatum and I. lamella Wilson, 1904 were the same species, because they have similar morphological features and were described in the same geographical zone (Galapagos Islands). Desqueyroux-Faúndez and van Soest (1996) reviewed the type material, as well as new material collected from South America, and considered that they belonged to the same species. The authors included the records of Iophon chelifer var. californiana de Laubenfels, 1930 (California) and Burtonella melanokhenia de Laubenfels, 1928 (Puget Sound, USA). van Soest et al. (2012) suggested that the records from California (de Laubenfels, 1928, 1930) are synonyms of I. lamella and consider that I. indentatum is a valid species. The main differences between these two species are the palmate anisochelae categories. Iophon lamella Wilson, 1904 has two categories of palmate anisochelae (I, 20$35 \mu \mathrm{m}$; II, 10-17.5 $\mu \mathrm{m}$ ) and Iophon indentatum Wilson, 1904 has one category $(10-17.5 \mu \mathrm{m})$.

\section{Iophon bipocillum $\mathrm{n}$. sp. (Figs 9D and 13, Table 7)}

Material examined. Holotype, MCNM 1.01/693, 09/04/2011, 20 Station Talud XIV (Gulf of California, MEX), $410 \mathrm{~m}\left(28^{\circ} 46^{\prime} 29^{\prime \prime} \mathrm{N}\right.$ $112^{\circ} 45^{\prime} 40 ”$ W). 2056-LEB-ICML-UNAM, 09/04/2011, 20 Station Talud XIV (Gulf of California, MEX), $410 \mathrm{~m}\left(28^{\circ} 46^{\prime} 29^{\prime \prime} \mathrm{N}\right.$ $\left.112^{\circ} 45^{\prime} 40^{\prime \prime W}\right) . \quad 2057-L E B-I C M L-U N A M, 09 / 04 / 2011$, Talud XIV 14 Station (Gulf of California, MEX), 410 m (28 46'29”N $112^{\circ} 45^{\prime} 40$ 'W). 2058-LEB-ICML-UNAM, 09/04/2011, 20 Station Talud XIV (Gulf of California, MEX), $410 \mathrm{~m}\left(28^{\circ} 36^{\prime} 14^{\prime \prime} \mathrm{N}\right.$ $\left.112^{\circ} 28^{\prime} 03^{\prime \prime} \mathrm{W}\right)$.

Description. Massive sponge 10-30 $\mathrm{cm}$ long and 3-5 cm thick. Surface smooth. Oscula circular to oval shaped (500-1200 um long) and ostia elliptical (50-100 $\mu \mathrm{m}$ long) and evenly distributed. Consistency elastic and easy to tear. Colour in life dark-brown, in preservation pale (Fig. 9D).

Skeleton. Ectosomal tylotes with microspined heads: 205-310×5-7.5 $\mu \mathrm{m}$ (Fig. 13A). Choanosomal styles straight or slightly curved: $320-425 \times 15-22.5 \mu \mathrm{m}$ (Fig. 13B). Bipocilla multidentate: 12.5-20 $\mu \mathrm{m}$ (Fig. $13 \mathrm{C}, \mathrm{D})$. The ectosomal skeleton is a dense layer of tylotes (10-20 $\mu \mathrm{m}$ thick). The choanosomal skeleton is an isotropic reticulum formed by ascending multispicular primary fibres (100-150 $\mu \mathrm{m}$ wide), interconnected by multispicular secondary fibres (45-70 $\mu \mathrm{m}$ wide). The organization forms quadrangular meshes (150-300 $\mu \mathrm{m}$ wide). Bipocilla are dispersed with no special organization.

Etymology. Named "bipocillum" because it is the only species bearing exclusively bipocilla as microscleres.

Remarks. Iophon bipocillum n. sp. is a deep sea species from the Gulf of California. It has styles, tylotes and bipocilla. I. bipocillum n. sp. is the only species of the genus bearing bipocilla as microscleres. Iophon species are characterized by having bipocilla and palmate anisochelae as microscleres. There are three species bearing exclusively palmate anisochelae: $I$. 
694 - J.M. Aguilar-Camacho et al.

TABLE 7. - Spicule measurements of Iophon bipocillum n. sp. in $\mu \mathrm{m}$. Values are expressed in minimum-average-maximum ( $\mu \mathrm{m})$.

\begin{tabular}{lcccc}
\hline Material examined & $\begin{array}{c}\text { Choanosomal styles } \\
\text { (length×width) }\end{array}$ & $\begin{array}{c}\text { Tylotes } \\
\text { (length×width) }\end{array}$ & $\begin{array}{c}\text { Bipocilla } \\
\text { (length) }\end{array}$ & Locality and depth \\
\hline MCNM 1.01/693 & $335-(372.3)-400 \times 15-(16.7)-20$ & $250-(271.5)-300 \times 5-(6.8)-7.5$ & $12.5-(16.7)-20$ & Gulf of California. 410 m \\
LEB-2056 & $320-(345.3)-380 \times 15-(17.6)-20$ & $205-(257.5)-285 \times 5-(4.5)-7.5$ & $12.5-(15.7)-20$ & Gulf of California. 410 m \\
LEB-2057 & $345-(380.7)-410 \times 15-(17.3)-22.5$ & $270-(287.5)-310 \times 5-(4.8)-7.5$ & $12.5-(16.1)-20$ & Gulf of California. 410 m \\
LEB-2058 & $360-(395.4)-425 \times 15-(18.1)-20$ & $260-(282.5)-300 \times 5-(6.2) 7.5$ & $15-(16.3)-20$ & Gulf of California. 410 m \\
\hline
\end{tabular}

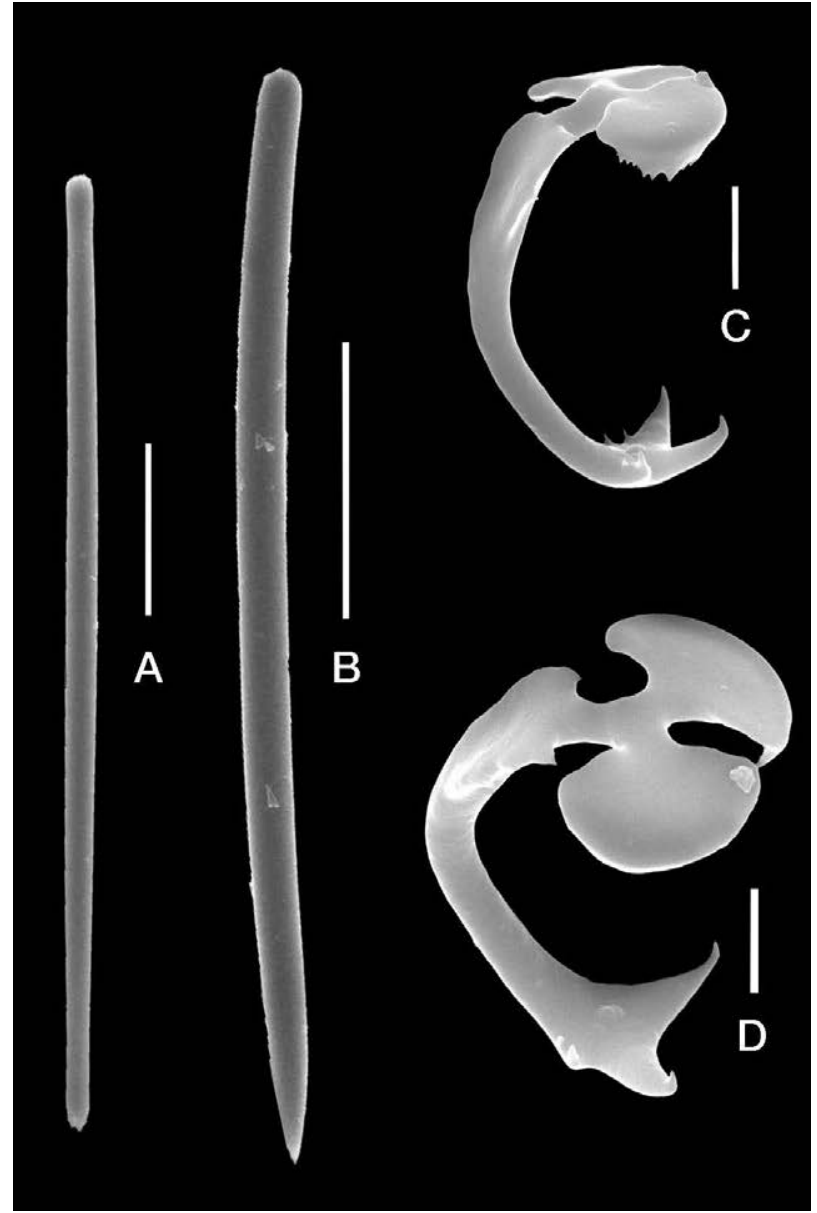

FIG. 13. - Iophon bipocillum n. sp. A, Ectosomal tylote with microspined heads. B, Choanosomal style. C, Bipocillae lateral view. D, Bipocillae view of the upper part. Scale: A, $40 \mu \mathrm{m} ; \mathrm{B}, 70 \mu \mathrm{m} ; \mathrm{C}, 3.5$ $\mu \mathrm{m} ; \mathrm{D}, 3 \mu \mathrm{m}$.

timidum Desqueyroux-Faúndez and van Soest, 1996 (South Pacific), I. pictoni Goodwin et al., 2011 (southwest Atlantic) and I. abnormale Ridley and Dendy, 1886 (Indian Ocean). Iophon species bear as choanosomal megascleres acanthostyles or styles. In the eastern Pacific there are only two species with styles. Iophon timidum Desqueyroux-Faúndez and van Soest, 1996 is a massive brown sponge, described from the coast of Chile at $25 \mathrm{~m}$ depth. It has styles $(186-259 \times 3-6 \mu \mathrm{m})$, tylotes with microspined heads $(150-250 \times 3-6 \mu \mathrm{m})$ and palmate anisochelae in two sizes (I, 10-16 $\mu \mathrm{m}$; II, 5-10 $\mu \mathrm{m})$. The styles are longer in I. bipocillum $\mathrm{n}$. sp. than I. timidum. Iophon tubiforme Desqueyroux-Faúndez and van Soest, 1996 is a brown tubular-shaped sponge described from the Chilean Coast. This species has choanosomal strongyles $(163-272 \times 5-13 \mu \mathrm{m})$, tylotes with microspined heads $(141-243 \times 3-10 \mu \mathrm{m})$, palmate anisochelae $(8-17 \mu \mathrm{m})$ and bipocilla $(6-19 \mu \mathrm{m})$. The main differences between these two species are the length and morphology of the choanosomal megascleres: strongyles with a smooth base in I. tubiforme shorter than the styles of Iophon bipocillum $\mathrm{n}$. sp.

\section{DISCUSSION}

Species belonging to the family Acarnidae have been reported in all the oceans worldwide (Hooper 2002a). In the Mexican Pacific, there were only three species known (Dickinson 1945), but after this study the number of species has increased to ten. Currently, there are 33 species of the family Acarnidae from the eastern Pacific region: 5 from Alaska (Stone et al. 2011), 8 from the Pacific Coast of the USA (Lee et al. 2007), 10 from the Mexican Pacific (including the Gulf of California) and 10 from South America (Desqueyroux-Faúndez and van Soest 1996).

Acarnus erithacus de Laubenfels, 1927 is found in the Gulf of California and on the Pacific coast of the USA. Acarnus peruanus van Soest et al. 1991 was originally described from the Pacific coast of Peru, and after this study its distributional range has now extended to include the Gulf of California. Iophon indentatum Wilson, 1904 is found in the southeast Pacific and in the Gulf of California. Iophon bipocillum n. sp. is a deep sea species from the Gulf of California. Megaciella microtoxa (Dickinson, 1945), Acarnus michoacanensis n. sp., Acarnus oaxaquensis n. sp., Acarnus sabulum n. sp., Acheliderma fulvum n. sp. and Megaciella toxispinosa $\mathrm{n}$. sp. are subtidal species found in specific localities from the Mexican Pacific.

Five of the ten species described in this study belong to the genus Acarnus. Three of them are new to science. There is a high diversity of species belonging to this genus in the Mexican Pacific. Acarnus is characterized by the presence of the cladotylote spicule, which is considered a synapomorphic feature in the family Acarnidae (Hooper 2002a). According to van Soest et al. (1991) the presence of this spicule is employed for the definition of the genus. However, there are species with a hymedesmoid, dendritic and isotropic skeleton and with and without echinating acanthostyles (see van Soest et al. 1991).

Iophon bipocillum $\mathrm{n}$. $\mathrm{sp}$. is by far the only species described worldwide bearing exclusively bipocilla as microscleres. The bipocillae studied with the help of the SEM recognized that the upper part bears two 
structures like clove leaves (Fig. 13D). The morphology of this microsclere has been described before (see Boury-Esnault and Rützler 1997). Recently, Goodwin et al. (2012) described a new species of the genus Iophon from South Georgia (I. husvikensis). The bipocillae shown in this species is most likely an anchoratemultidentate chela instead of a real bipocillae.

The ectosomal spicule morphology is a diagnostic feature to assign species in the suborder Microcionina (Hajdu et al. 1994). Species with diactinal spicules are assigned in the family Acarnidae and with monactinal spicules in the family Microcionidae (Hooper, 2002a). Recently, de Barros et al. (2013) described a new species of the genus Clathria from the coast of Brazil ( $C$. (Clathria) nicoleae). This species has ectosomal tylostrongyles with microspined heads, choanosomal subtylostyles with a smooth or microspined base, echinating acanthostyles, toxas and palmate isochelae. We think that this species does not belong to the family Microcionidae, because it has ectosomal diactinal spicules. Based on the recent description, this species may move to the genus Megaciella (family, Acarnidae). There are also some species assigned to the genus Clathria with ectosomal diactinal spicules such as C. (Clathria) basilana Lévi, 1961 and C. (Clathria) chelifera (Hentschel, 1911) (see Hooper 1996). They do not belong to the family Microcionidae and need to be transferred to a specific genus of the family Acarnidae. This is the first taxonomic contribution of a family belonging to the suborder Microcionina from the Mexican Pacific.

\section{ACKNOWLEDGEMENTS}

We thank Regina Wetzer from the Natural History Museum of Los Angeles County for inviting the first author to review the Allan Hancock Sponge Collection; Kathy Omura, Emma Freeman and Kirk Fitzhugh for their help; Yolanda Hornelas (ICML) and Ing. Israel Gradilla Martinez (CNCyN-UNAM, Ensenada) for the SEM photographs. Clara Ramírez Jáuregui (ICML) helped with the literature. We thank SAGARPA for the permit number DGOPA.00978.120209.0457 conferred for the collection of the samples. This research was partially supported by the project SEP-CONACyT (102239). We thank the Consejo Técnico de Investigación Científica, UNAM, for providing time to use the R/V El Puma as well as scientific staff and crew for their support in sampling operations during the Talud XIV campaign. The constructive comments of M.J. Uriz and two anonymous reviewers improve this manuscript.

\section{REFERENCES}

Bakus G.J. 1966. Marine poeciloscleridan sponges of the San Juan Archipelago, Washington. J. Zool. 149:415-531.

Barros L.D. de., Santos G.G., Pinheiro U. 2013. Clathria (Clathria) Schmidt, 1862 from Brazil with description of a new species and a review of records (Poecilosclerida: Demospongiae: Porifera). Zootaxa 3640(2): 284-295.

Boury-Esnault N. 1973. Résultats Scientifiques des Campagnes de la 'Calypso'. Campagne de la 'Calypso' au large des côtes atlantiques de l'Amérique du Sud (1961-1962) I. Spongiaires. Ann. Inst. Oceanogr. 49(Suppl. 10): 263-295.

Boury-Esnault N., Rützler K. 1997. Thesaurus of Sponge Morphology. Smithson. Contrib. Zool. 596: 1-55.

Carter H.J. 1885. Descriptions of Sponges from the Neighbourhood of Port Phillip Heads, South Australia. Ann. Mag. Nat. Hist. 16(94): 277-294, 347-368.

Dendy A. 1896. Catallogue of Non-Calcareous Sponges collected by J. Bracebridge Wilson, Esq., M.A., in the neighbourhood of Port Phillip Heads. Part II. Proc. Royal Soc. Victoria (New Ser.) 8: $14-51$.

Dendy A. 1922. Report on the Sigmatotetraxonida collected by H.M.S. 'Sealark' in the Indian Ocean. In: Reports of the Percy Sladen Trust Expedition to the Indian Ocean in 1905, Volume 7. Trans. Linn. Soc. Lond. 18(1):1-164.

Desqueyroux R. 1972. Demospongiae (Porifera) de la Costa de Chile. Gayana 20: 3-71.

Desqueyroux-Faúndez R., van Soest R.W.M. 1996. A review of Iophonidae, Myxillidae and Tedaniidae occurring in the South East Pacific (Porifera: Poecilosclerida). Rev. Suiss. Zool. 103(1): 3-79.

Dickinson M.G. 1945. Sponges on the Gulf of California. Allan Hancock. Pac. Exp. 11(1): 1-251.

Goodwin C., Brewin P.E., Brickle P. 2012. Sponge biodiversity of South Georgia island with descriptions of fifteen new species. Zootaxa 3542: 1-48.

Goodwin C., Jones J., Neely K., Brickle P. 2011. Sponge biodiversity of the Jason Islands and Stanley, Falkland Islands with descriptions of twelve new species. J. Mar. Biol. Ass. U.K. 91(2): 275-301.

Gray J.E. 1867. Notes on the Arrangement of Sponges, with the Descriptions of some New Genera. Proc. Zool. Soc. Lond. 1867(2): 492-558.

Hajdu E., van Soest R.W.M., Hooper J.N.A. 1994. Proposal for a phylogenetic subordinal classification of poecilosclerid sponges. In: van Soest R.W.M., van Kempen Th.M.G., Braekman J.C. (eds), Sponges in Time and Space. Balkema, Rotterdam, pp. 123-139.

Hallmann E.F. 1920. New Genera of Monaxonid Sponges related to the Genus Clathria. Proc. Linn. Soc. N.S.W. 44(4): 767-792.

Hentschel E. 1911. Tetraxonida. 2. Teil. In: Michaelsen W., Hartmeyer R. (eds.), Die Fauna Südwest-Australiens. Ergebnisse der Hamburger südwest-australischen Forschungsreise, Volumen 3. Fischer, Jena, pp 279-393.

Hofknecht G. 1978. Descriptions and key to the intertidal sponges of the Puerto Peñasco area in the Gulf of California. J. ArizonaNevada Acad. Sci. 9(1): 51-56.

Hooper J.N.A. 1996. Revision of Microcionidae (Porifera: Poecilosclerida: Demospongiae), with description of Australian species. Mem. Q'land. Mus. 40:1-626.

Hooper J.N.A. 2002a. Family Acarnidae Dendy, 1922. In: Hooper J.N.A., van Soest R.W.M. (eds), Systema Porifera: A Guide to the Classification of sponges. 1. Kluwer Academic/ Plenum Publishers: New York, pp. 412-431.

Hooper J.N.A. 2002b. Family Microcionidae Carter, 1875. In: Hooper J.N.A., van Soest R.W.M. (eds.), Systema Porifera: A Guide to the Classification of sponges. 1. Kluwer Academic/ Plenum Publishers: New York, pp. 432-468.

Koltun V.M. 1959. Siliceous horny sponges of the northern and far Eastern seas of the U.S.S.R. Opredeliteli po faune SSR izdavaemye Zoologicheskim muzeem Akademii nauk. (In Russian), $236 \mathrm{pp}$.

Laubenfels M.W. de. 1927. The red sponges of Monterey Peninsula, California. Ann. Mag. Nat. Hist. 19: 258-266.

Laubenfels M.W. de. 1928. A New Genus and Species of Sponges From Puget Sound. Publs. Puget Sound Mar. Biol. Stat. Univ. Washington. 5: 361-363.

Laubenfels M.W. de. 1930. The Sponges of California. (Abstracts of dissertations for the degree of doctor of philosophy) Stanf. Univ. Bull. 5(98): 24-29.

Laubenfels M.W. de. 1932. The marine and fresh-water sponges of California. Proc. U. S. Nat. Mus. 81(2927): 1-140.

Laubenfels M.W. de. 1936. A Discussion of the Sponge Fauna of the Dry Tortugas in Particular and the West Indies in General, with Material for a Revision of the Families and Orders of the Porifera. Pap. Tortugas Lab. Carnegie Institution. 30:1-225. 
Lee W.L., Elvin D.W., Reiswig H.M. 2007. The Sponges of California. A guide and key to the marine sponges of California. Monterey Bay Sanctuary Foundation, California.

Lévi C. 1952. Spongiaires de la côte du Sénégal. Bull. Inst. Fr. Afr. Noire. 14(1): 34-59.

Lévi C. 1961. Spongiaires des Iles Philippines, principalement récoltées au voisinage de Zamboanga. Philipp. J. Sci. 88(4): 509-533.

Ridley S.O., Dendy A. 1886. Preliminary Report on the Monaxonida collected by H.M.S. 'Challenger'. Ann. Mag. Nat. Hist. 18: 325-351, 470-493.

Stone R.P., Lehnert H., Reiswig H. 2011. A guide to deep-water sponges of the Aleutian Island Archipelago. NOAA Professional Paper NMFS.

Tanita S. 1963. Report on the non-calcareous sponges in the museum of the Biological Institute of the Tohoku University, II. Sci. Rep. Tôhoku Univ. 19: 121-129.

Thiele J. 1903. Kieselschwämme von Ternate. II. Abh. Senckenberg. Naturforsch. Ges. 25: 933-968.

Topsent E. 1892. Diagnoses d'éponges nouvelles de la Méditerranée et plus particulièrement de Banyuls. Arch. Zool. Exp. Gén. 10(6): 17-28.

Topsent E. 1927. Diagnoses d'Éponges nouvelles recueillies par le Prince Albert ler de Monaco. Bull. Inst. océanogr. Monaco 502: $1-19$.

Uriz M.J., Turon X., Becerro M.A. 2000. Silica deposition in Demosponges: spiculogenesis in Crambe crambe. Cell Tissue Res. 301(2): 299-309.

Vacelet J., Vasseur P. 1971. Éponges des récifs coralliens de Tuléar
(Madagascar). Téthys 1: 51-126.

van Soest R.W.M. 2009. New sciophilous sponges from the Caribbean (Porifera: Demospongiae). Zootaxa 2107: 1-40.

van Soest R.W.M., Hooper J.N.A., Hiemstra F. 1991. Taxonomy, phylogeny and biogeography of the marine sponge genus Acarnus (Porifera: Poecilosclerida). Beaufortia 42(3): 49-88.

van Soest R.W.M., Zea S., Kielman M. 1994. New species of Zyzzya, Cornulella, Damiria, and Acheliderma (Porifera: Poecilosclerida), with a review of fistular genera of Iophonidae. Bijdr. Dierk. 64: 163-192.

van Soest R.W.M., Boury-Esnault N., Hooper J.N.A, Rützler K., de Voogd N.J., Alvarez de Glasby B., Hajdu E., Pisera A.B., Manconi R., Schoenberg C., Janussen D., Tabachnick K.R, Klautau M., Picton B., Kelly M. 2012. World Porifera Database. Available from: http://www.marinespecies.org/porifera (accessed October 2012)

Wilson H.V. 1904. Reports on an Exploration off the West Coasts of Mexico, Central and South America, and off the Galapagos Islands, in charge of Alexander Agassiz, by the U.S. Fish Commission Steamer 'Albatross' during 1891, Lieut. Commander Z.L. Tanner, U.S.S., commanding. XXX. The Sponges. Mem. Mus. Comp. Zool. Harv. 30(1): 1-164.

Wilson H.V. 1925. Silicious and horny sponges collected by the U.S. Fisheries Steamer 'Albatross' during the Philippine Expedition, 1907-10. U.S. Natl. Mus. Bull. 2(4): 273-532.

Scient. ed.: M.J. Uriz.

Received December 17, 2012. Accepted October 7, 2013.

Published online November 6, 2013. 